\title{
1 Inactivation effects of plasma-activated water on Fusarium graminearum
}

2 Jian Guo ${ }^{\mathrm{a}}$, Jiaoyu Wang ${ }^{\mathrm{b}}$, Hui Xie ${ }^{\mathrm{a}}$, Junlong Jianga, Chunyuan $\mathrm{Li}^{\mathrm{a}}$, Wanting Li ${ }^{\mathrm{a}}$, Ling $\mathrm{Li}^{\mathrm{a}}$, Xingquan

$3 \quad$ Liu $^{\mathrm{a}}$, Fucheng Lin ${ }^{\mathrm{b}, \mathrm{c}}$

$4 \quad{ }^{a}$ College of Agriculture and Food Science, Zhejiang Agriculture \& Forestry University, No. 666 Wusu

$5 \quad$ Street, Hangzhou 311300 , China

$6 \quad{ }^{\mathrm{b}}$ State Key Laboratory for Managing Biotic and Chemical Treats to the Quality and Safety of Agro-

7 products, Institute of Plant Protection and Microbiology, Zhejiang Academy of Agricultural Sciences,

8 Hangzhou 310021, China

$9 \quad{ }^{\mathrm{c}}$ Institute of Biotechnology, Zhejiang University, Hangzhou, 310058, China

\section{Abstract}

The continuous usage of fungicides poses a potential threat to the environment, ranging from mere irritation to being very toxic to human beings and organisms. Plasma-activated water (PAW) has recently gained much interest as a promising candidate to inactivate fungi. However, the inactivation mechanisms of PAW are still not well understood. In this study, the effect of PAW on the viability and the cellular responses of Fusarium graminearum in PAW inactivation were investigated. The results showed that microbial activity of spores was significantly inhibited by PAW treatment $(P<0.05)$. The symptoms caused by F. graminearum were significantly reduced on the spikelets. Our data indicated that PAW could induce cell wall sculpturing, membrane permeability changes, and mitochondrial dysfunction. Differential gene expression analysis also confirmed that the cell membrane, the cell wall and the

\footnotetext{
* Corresponding author.
}

E-mail: liling-06@163.com 

development of PAW as a potential fungicidal agent or an effective supplement to fungicides.

Keywords Inactivation mechanism; Pathogen; Reactive oxygen species; Eco-friendly fungicide; 


\section{Introduction}

Phytopathogens are the main causes of plant diseases, they significantly reduce the yield of agricultural crops (McMullen et al., 1997; Marcos et al., 2008). The use of fungicides in modern agricultural practices has made crop production stable, and environmental and food safety issues associated with the use of fungicides cannot be ignored. Prolonged or repeated application of agricultural chemicals has led to the outbreak of acute or chronic diseases, toxicity to nontarget organisms, excessive fungicide residues, and groundwater and surface water contamination (Pimentel et al., 1992; Soylu et al., 2010). Fusarium graminearum is an ascomycetous fungus that is the major cause of Fusarium head blight (FHB) on wheat and barley, as well as stalk and ear rot disease on maize. This fungus not only causes crop yield and quality losses but also contaminates grain with mycotoxins, rendering them unfit for food or feed (Etzerodt et al., 2016; Kim and Vujanovic, 2016; Masci et al., 2015; Zhou et al., 2021). Benzimidazoles and sterol demethylation inhibitors are widely used for the control of FHB (Blandino et al., 2006; Bian et al., 2021). However, these synthetic chemicals are difficult to degrade and are harmful to the environment and human health (Zheng et al., 2019). Therefore, much attention has been given to the development of highly efficient, environmentally friendly, and low-residue novel antifungal agents.

Cold plasma is an electrically energized matter in a gaseous state that is composed of charged particles, free radicals, and some radiation. To obtain cold plasma, an electrical discharge device is needed, which is not convenient for practical applications. Plasma treatment of water, termed plasmaactivated water (PAW), alters the physicochemical properties of water, such as the redox potential, $\mathrm{pH}$ and conductivity. As a result, PAW has a different chemical composition than water and can serve as an alternative method for microbial disinfection (Ercan et al., 2013; Guo et al., 2021; Natali et al., 2010; 
Oehmigen et al., 2010; Puligundla et al., 2018; Shen et al., 2016; Traylor et al., 2011; Tian et al., 2015; Xiang et al., 2019a; Xu et al., 2020; Zhang et al., 2016). Reactive oxygen and nitrogen species (RONS) are the major agents for air-plasma-induced biological effects, and almost no harmful byproducts are generated in the plasma treatment process (Xu et al., 2020). In our previous study, the oxidative stress and acidity of PAW were not persistent (Guo et al., 2017; Guo et al., 2021; Shen et al., 2016). The lifetime of the chemical components in PAW is short and labile (Brisset et al., 2011; Girard et al., 2016; Pavlovich et al., 2013), and it leaves less residue and harmful chemical components on crops than conventional approaches. Thus, PAW can be regarded as a promising eco-friendly approach for fungal inactivation. Previous studies have showen that chemical components generated in PAW and the oxidative stress it induces play major roles during PAW treatments (Natali et al., 2010; Oehmigen et al., 2010; Pavlovich et al., 2013; Zhang et al., 2013). It is generally accepted that different plasma devices and working gases could lead to different inactivation efficiencies and inactivation patterns. For instance, oxygen-containing gases can increase the proportion of reactive oxygen species (ROS) leading to a higher inactivation efficiency. It was also found that ROS play an important role in direct plasma inactivation in an aqueous environment (Chandana et al., 2018; Gorbanev et al., 2018; Guo et al., 2021; Xu et al., 2020). Kaneko et al. (2017) found that $\cdot \mathrm{OH}$ plays a key role in gas-liquid interfacial plasma irradiation. Xu et al., (2020) reported that ${ }^{1} \mathrm{O}_{2}$ contributes the most to the yeast cells. Because of the complexity of the reactive species in plasma and the different roles played by short- and long-lived ROS, the cold plasma inactivation mechanisms caused by these RONS in an aqueous environment or PAW are not yet fully understood. 
responses to cold plasma treatment or PAW treatment. Many works have reported that different types of microorganisms behave differently in their interactions with RONS in cold plasma or PAW. Xiang et al. (2019b) found that gram-negative $E$. coli bacteria were more sensitive to PAW than the gram-positive $S$. aureus bacteria, which might be due to the significant differences in the cell wall structures of gramnegative and gram-positive bacteria, especially the thickness of the peptidoglycan layer. Han et al. 2016 reported that cold plasma inactivated E. coli mainly through damaging the cell wall, while $S$. aureus was inactivated by cold plasma primarily through damaging the intracellular components. Furthermore, it is commonly considered that fungal resistance against cold plasma is generally higher than that in bacteria due to the complex cell wall structure and specialized cellular organelles (such as mitochondria and ribosomes) (Xu et al., 2020). The cell wall of fungi consists of chitin, which is more rigid than the peptidoglycan of bacterial cell walls. Lunov et al. (2016) reported that plasma could induce two different inactivation mechanisms (apoptosis or direct physical destruction) in bacteria depending on the plasma treatment time. Xu et al. (2020) also revealed that yeast cells underwent apoptosis in the first $3 \mathrm{~min}$ of treatment due to the accumulation of intracellular ROS, mitochondrial dysfunction and intracellular acidification, followed by necrosis under longer exposure times, attributed to the destruction of the cell membrane. Itooka et al. (2018) revealed that cold plasma could cause protein denaturation and endoplasmic reticulum stress in Saccharomyces cerevisiae. However, studies that focus on the cellular responses in the PAW inactivation of fungi are very limited, especially from the perspective of gene expression.

In this work, the efficacy of PAW against $F$. graminearum in vivo and in vitro was first estimated by calculating the disease severity index and assessing the effects of PAW on mycelium growth, conidium germination and conidiation. The complicated cellular responses of $F$. graminearum to PAW 

expression.

\section{Materials and methods}

\subsection{Fungal culture conditions}

The Fusarium graminearum PH-1 strain used in this study was obtained from the Agricultural Culture Collection of China (Beijing, China). F. graminearum was aseptically inoculate in liquid complete medium $(\mathrm{CM})$ at $30^{\circ} \mathrm{C}$ for $7 \mathrm{~d}$. The strain was routinely cultured on $\mathrm{CM}$ plates at $28^{\circ} \mathrm{C}$ for mycelial growth assays. For the conidial germination assay, three mycelial plugs of the strain were inoculated in $30 \mathrm{~mL}$ of liquid $\mathrm{CM}$ under continuous light. After incubation in a shaker at $180 \mathrm{rpm}$ at $28{ }^{\circ} \mathrm{C}$ for $7 \mathrm{~d}$, conidia of each sample were collected by centrifugation and were quantified using a hemocytometer.

\subsection{Plasma treatment system}

The cold plasma device and operation method were described in our previous work (Guo et al., 2021). Sterile distilled water $(200 \mathrm{~mL})$ was activated by plasma treatment for $15,30,45$ and $60 \mathrm{~min}$. Accordingly, the samples after treatment were named as PAW15, PAW30, PAW45 and PAW60, and the control.

\subsection{Physicochemical properties of $P A W$}

To evaluate the physicochemical properties of PAW, the conductivity, oxidation reduction potential (ORP), and $\mathrm{pH}$ of PAW were all detected using a multimeter (Orion $3 \mathrm{Star} \mathrm{pH} / \mathrm{ORP}$ Meter, Thermo 
111 Fisher Scientific Inc, PA) immediately after production. ORP was used to estimate the oxidative stress

112 in PAW, the concentration of the oxidizers and their activity or strength (Mcferson, 1993).

$1 \mathrm{M}$ hydrochloric acid and $100 \mu \mathrm{l}$ of $0.8 \%$ sulfamic acid. $\mathrm{NO}_{3}{ }^{-}$levels in PAW samples were determined wavelength of $220 \mathrm{~nm}$.

For the determination of $\mathrm{NO}_{2}^{-}$, sulphanilamide was used as the diazotizing reagent, and $\mathrm{N}-(1$ naphthy1)-ethylenediamine hydrochloride was used as the coupling reagent. After plasma activation, 1 $\mathrm{mL}$ of sulphanilamide solution $(5 \mathrm{~g}$ of sulphanilamide was dissolved in a mixture of $50 \mathrm{~mL}$ of $37 \%(\mathrm{w} / \mathrm{w})$ concentrated $\mathrm{HCl}$ and $300 \mathrm{~mL}$ of water, and it was diluted to $500 \mathrm{~mL}$ with water) was added into $50 \mathrm{~mL}$ of PAW, and incubated at room temperature for $2 \mathrm{~min}$, subsequently adding $1 \mathrm{~mL}$ of $1.0 \mathrm{~g} \mathrm{~L}^{-1} \mathrm{~N}-(1-$ naphthy1)-ethylenediamine hydrochloride at room temperature. After a 20-min incubation at room temperature, the absorbance at $540 \mathrm{~nm}$ was measured using a spectrophotometer (UV-1800, Shimadzu Corporation, Kyoto, Japan) for the determination of the concentrations of $\mathrm{NO}_{3}{ }^{-}$in the PAW.

\subsection{In vivo fungicidal activities assay}

The in vivo fungicidal activities of PAW against $F$. graminearum (strain $\mathrm{PH}-1)$ were evaluated as follows: The spikelets were point-inoculated with $20 \mu$ of the conidial suspension $\left(10^{5}\right.$ conidia $\left.\mathrm{mL}^{-1}\right)$ mixed with PAW. After inoculation, the spikelets were placed in a controlled chamber (90-100\% relative 
divided by the total area of the wheat $\times 100 \%$ ). The protection efficacies were calculated as follows:

Protection efficacy $=[($ mean area of infected spikelets of control - mean area of infected spikelets of treated group $/$ mean area of infected spikelets of control] $\times 100 \%$.

\subsection{In vitro fungicidal activities assay}

For the mycelium growth assay, $2 \mathrm{~mL}$ of PAW was transferred into the test tubes containing $0.5 \mathrm{~mL}$ of $F$. graminearum spore suspension. After exposure for $1 \mathrm{~h}, 10 \mu \mathrm{l}$ of $F$. graminearum spore suspension was dropped at the center of $\mathrm{CM}$ or $\mathrm{CR}$ (Congo red was added to complete medium to $100 \mu \mathrm{g} \mathrm{mL}^{-1}$ or $200 \mu \mathrm{g} \mathrm{mL}^{-1}$ ) and CFW (calcofluor white was added to complete medium to $50 \mu \mathrm{g} \mathrm{mL}^{-1}$ ) plates. The agar plates were incubated at $28^{\circ} \mathrm{C}$. Sterile water $(2 \mathrm{~mL})$ was used as the control. The colonial diameters of the treated strain were carefully measured by a caliper, every $12 \mathrm{~h}$ over $5 \mathrm{~d}$, and the inhibition ratios were calculated using the following formulas:

$$
I=\left(\frac{\left(D_{c}-D_{t}\right)}{D_{c}}\right) \times 100 \%
$$

where $D_{c}$ and $D_{t}$ are the colonial diameters of the control and treated groups, respectively.

The dry weight of the mycelial biomass was measured after 7 days of cultivation in liquid $\mathrm{CR}$ or CFW medium.

Conidiation was assessed by growing the strain in liquid complete medium (CM) for 7 days. The conidial concentration was measured using a hemocytometer.

For the conidial germination assay, spores from strain $\mathrm{PH}-1$ were inoculated in the liquid $\mathrm{CM}$ in the presence of PAW or were left untreated. PAW15, PAW30, PAW45 and PAW60 (0.4 mL) were transferred into tubes that contained an $F$. graminearum spore suspension $(0.1 \mathrm{~mL})$, and the mixture was 
allowed to stand for $1 \mathrm{~h}$. Five microliters of the treated conidia was pipetted onto the concave slide at 25

${ }^{\circ} \mathrm{C}$ for $6 \mathrm{~h}$ and then observed by fluorescence microscopy (Nikon Eclipse Ti-s; Tokyo, Japan) for the analysis of germ tube emergence. Sterile water $(0.4 \mathrm{~mL})$ was used as the control. Three different fields of view were observed randomly. The number of conidia observed in each test was at least 200 . Although germ tube emergence marks the culmination of the germination process, it was used as a convenient marker for germination in our experiments (Semighini et al., 2008). The conidial germination ratios were calculated using the following formulas:

$$
\mathrm{R}=\mathrm{N}_{\mathrm{g}} / \mathrm{N}_{\mathrm{t}} \times 100 \%
$$

where $\mathrm{R}$ is the conidial germination ratio, $\mathrm{N}_{\mathrm{g}}$ is the conidial germination number, and $\mathrm{N}_{\mathrm{t}}$ is the conidial number.

The relative conidial germination ratios were calculated using the following formula:

$$
\mathrm{R}_{\mathrm{e}}=\mathrm{R}_{\mathrm{t}} / \mathrm{R}_{\mathrm{c}} \times 100 \%
$$

where $R_{e}$ is the relative conidial germination ratio, and $R_{t}$ and $R_{c}$ are the conidial germination ratios of the treated and control groups, respectively.

\subsection{Effect of PAW on cell wall integrity}

The effect of PAW on cell wall integrity was assayed by measuring the conidiation and dry mycelial weight of the strain grown in liquid $\mathrm{CM}$ supplemented with $100 \mathrm{mg} \mathrm{L}^{-1}, 200 \mathrm{mg} \mathrm{L}^{-1}$ Congo red and 50 $m g \mathrm{~L}^{-1}$ Calcofluor White for 7 days.

\subsection{SEM and TEM observations}

To investigate the effect of PAW on the spore cell wall. We performed transmission electron 
microscopy (TEM) imaging. After PAW treatment, the spores were fixed in Karnovsky's fixative ( $2 \%$ $\mathrm{v} / \mathrm{v}$ paraformaldehyde and $2 \% \mathrm{v} / \mathrm{v}$ glutaraldehyde in $1 \mathrm{x}$ PBS) overnight. The specimens were observed using a Hitachi Model H-7650 TEM (Hitachi High-Tech Manufacturing \& Service, Corp).

\subsection{Measurement of nucleic acid and protein leakage}

Spore cell membrane integrity was detected by determining the release of intracellular components absorbing at $260 \mathrm{~nm}$ and $280 \mathrm{~nm}$ as described in the relevant literature (Cockrell et al., 2017; Xiang et al., 2018) with slight changes. Spores were harvested by centrifugation at $5000 \mathrm{xg}$ for $10 \mathrm{~min}$ at $4{ }^{\circ} \mathrm{C}$, and were then suspended in sterile deionized water. PAW15, PAW30, PAW45 and PAW60 were added to spores suspensions. Spores treated with PAW0 were used as the control. To quantify the concentrations of nucleic acids and proteins, the optical densities of the supernatants at $260 \mathrm{~nm}$ and $280 \mathrm{~nm}$ were recorded.

\subsection{Measurement of mitochondrial activity and total microbial activity}

Spores were labeled with tetramethylrhodamine methyl ester (TMRM, $80 \mathrm{nM}$ ) for mitochondria after PAW treatment. The cells were then washed three times and resuspended in PBS for observation.

Imaging of cells loaded with fluorescent dyes was performed using a Zeiss LSM510 system (Carl Zeiss,

Germany). The excitation wavelength was $543 \mathrm{~nm}$ and the emission was collected between 561 and 603 $\mathrm{nm}$.

A stock solution of $500 \mu \mathrm{g} \mathrm{mL}^{-1} \mathrm{FDA}$ was made in acetone and then diluted to $100 \mu \mathrm{g} \mathrm{mL}^{-1}$ in incubation buffer. The cells were then washed three times and resuspended in PBS for observation. Fluorescein was excited using a $488 \mathrm{~nm}$ laser, and the emission was collected between 505 and $530 \mathrm{~nm}$. 


\subsection{RNAseq and transcriptomic analyses.}

Fungal materials were frozen in liquid nitrogen and RNA was extracted using TRIzol ${ }^{\circledR}$ Reagent according to the manufacturer's instructions (Invitrogen), and genomic DNA was removed using DNase I (TaKaRa). The RNA-seq transcriptome library was prepared following the TruSeq ${ }^{\mathrm{TM}}$ RNA sample preparation kit from Illumina (San Diego, CA) using $1 \mu \mathrm{g}$ of total RNA. After quantification by TBS380, the paired-end RNA-seq sequencing library was sequenced using an Illumina HiSeq xten/NovaSeq 6000 sequencer $(2 \times 150$ bp read length). To identify DEGs (differentially expressed genes) between two different samples, the expression level of each transcript was calculated according to the fragments per kilobase of exon per million mapped reads (FRKM) method. RSEM was used to quantify gene abundances (Li and Dewey 2011). Differential gene expression analysis was performed with DESeq2 software based on negative binomial distribution.

\subsection{Quantitative PCR}

To evaluate the validation of RNA-seq transcriptome results, primers (Table 2) were designed for the following thirteen candidates selected based on the following criteria: the highest upregulated gene involved in mitochondrial function and the highest upregulated or the lowest downregulated gene involved in cell wall and membrane integrity. Quantitative PCR (Q-PCR) assays were conducted according to the relevant literature (Liu et al., 2010; Demissie et al., 2018) with slight changes. Normalized relative expression values $\left(\Delta \Delta \mathrm{C}_{\mathrm{T}}\right)$ of the selected candidates were calculated using the formula $2^{-\Delta \Delta C T}$ (Livak and Schmittgen, 2001) using actin as a reference gene. Three amplifications were performed for each replicate. The expression of each tested gene in the PAW-treated sample relative to 
212 that of the untreated sample was calculated according to the fragments per kilobase of exon per million mapped reads (FRKM) method. compare the means.

\section{Results and discussion}

\subsection{Physicochemical properties of PAW} concentrations of nitrate and nitrite in PAW increased significantly $(P<0.05)$ over air-plasma-activated time. Patangea et al. (2019) also reported that PAW generated using this submerged DBD air-plasma 
indicator in water disinfection applications because there is a direct correlation between high ORP and cell membrane damage (Ma et al., 2015; Tian et al., 2015; Xiang et al., 2018). As shown in Fig. 1b, the ORP of water after plasma activation increased from $235.8 \pm 5.43 \mathrm{mV}$ to $394.9 \pm 23.69 \mathrm{mV}$, and an increase in the ORP was observed with prolonged plasma-activation time $(P<0.05)$. Similar results were also obtained in previous work (Guo et al., 2021; Tian et al., 2015; Xu et al., 2016; Xu et al., 2020). The discharged gases in these previous works all contain oxygen, which is the same as our study. Hence, a longer duration of plasma activation results in a larger amount of reactive oxygen species generated in PAW and a high ORP value.

The $\mathrm{pH}$ values of PAW over the plasma-activated time were also measured (Fig. 1c). The pH value of water after plasma activation decreased significantly $(P<0.05)$ from $7.44 \pm 0.010$ to $4.234 \pm 0.010$. However, after $45 \mathrm{~min}$ of plasma activation, the extended treatment time did not significantly influence the $\mathrm{pH}$ values of PAW, which decreased over the plasma-activated time. Plasma discharge acidified activated water (Oehmigen et al., 2010; Tian et al., 2015; Zhang et al., 2013; Xu et al., 2016). Due to the discharge gases, some nitrate and nitrite were generated in PAW. Prolonged plasma activation corresponds to larger amounts of hydrogen nitrate and nitrous acid, which lead to a lower $\mathrm{pH}$ value.

The electrical conductivity can indicate the concentrations of free ions present in an electrolytic solution. The electrical conductivity of PAW was measured before and after plasma activation (Fig. 1d). The conductivity of water after plasma activation increased from $2.3 \pm 0.3 \mu \mathrm{S} \mathrm{cm}^{-1}$ to $430.2 \pm 1.1 \mu \mathrm{S} \mathrm{cm}^{-1}$. The electrical conductivity of PAW increased in a plasma activation time-dependent manner, which provided evidence for the accumulation of active ions in PAW. The results demonstrated that many active ions were generated in PAW, which may be nitrate acid derived from chemical reactions between electrons or RNS in cold plasma and water molecules (Guo et al., 2021; Ma et al., 2015). 


\subsection{In vivo fungicidal activities assay}

To determine the fungicidal activities of PAW against FHB, the protection efficacies and disease severity indices were calculated. The symptoms caused by the pathogen were significantly reduced on

the spikelets (Fig. 2). The pathogen treated by PAW generally failed to colonize the inoculated spikelets.

The protection efficacies of PAW15, PAW30, PAW45 and PAW60 were $67.8 \%, 57.4 \%, 92.7 \%$ and

$86.8 \%$, respectively. Evaluations of disease development, which were quantified by calculating the activity $(P<0.05)$ against FHB compared with the control.

field. Compared to chemical synthetic fungicides, PAW has a similar protection efficacy (Chen et al., approximately 9 days (Guo et al., 2021). The half-value period may decrease when PAW is used outdoors. 
of antifungal activity than chemical synthetic fungicides.

\subsection{Effect of PAW on mycelium growth, conidiation, conidium germination and total microbial activity}

The results showed that the radial growth of $F$. graminearum was severely $(P<0.05)$ inhibited after PAW treatment (Fig. 3a). After $12 \mathrm{~h}$ of incubation, the mycelium length of PAW15-treated $F$. graminearum was $0.33 \pm 0.58 \mathrm{~mm}$, whereas that of the control group was $1.56 \pm 0.43 \mathrm{~mm}$. The mycelium length of F. graminearum did not increase after treatment with PAW30, PAW45, and PAW60. After incubation for $24 \mathrm{~h}$, the radical growth of $F$. graminearum treated with PAW60 was still severely inhibited, but the mycelium lengths of the PAW45, PAW30, and PAW15 groups reached 1.46 \pm 0.44 , $1.31 \pm 0.13$, and $3.88 \pm 1.16 \mathrm{~mm}$, respectively. After incubation for $36 \mathrm{~h}$, a general increase in radial growth of $F$. graminearum treated with PAW60 was observed. Treatment with PAW led to an approximately $30 \%$ reduction in biomass production in comparison to untreated samples (Fig. 3b). The inhibition ratios of mycelium growth are shown in Fig. 3c. Twelve hours after treatment, the PAW30, PAW45, and PAW60 still demonstrated complete inhibition of mycelial growth. Twenty-four hours after treatment, only PAW60 completely inhibited mycelial growth. After $36 \mathrm{~h}$ of incubation, the inhibition ratio of mycelium growth in the PAW60 group decreased. These results were in line with those of previous studies showing that fungi were effectively inactivated as the plasma activation time increased (Ercan et al., 2013; Tian et al., 2015; Zhang et al., 2013; Ma et al., 2015). The results suggest that PAW treatment inhibited mycelial growth in a plasma-activated time-dependent manner.

PAW treatment could inhibit the germination of $F$. graminearum spores. The $\mathrm{pH}$ value of PAW decreased over plasma activation time. However, previous studies demonstrated that $\mathrm{pH}$ has no effect on F. graminearum germination (Beyer et al., 2004; Depasquale and Montville, 1990). Studies have 
distinguished PAW-mediated inhibition from inhibition caused by $\mathrm{pH}$ alone, and the results have suggested that the inhibitory effect on conidium germination was mainly due to the introduction of PAW. The relative conidium germination ratios of $F$. graminearum treated with PAW15, PAW30, PAW45, and PAW60 are shown in Fig. 3d. Similar results were reported after spores were treated with farnesol, i.e., after $6 \mathrm{~h}, 44 \%$ of them failed to germinate (Semighini et al., 2008). The results of our study also indicated that the antifungal activity of PAW increased over plasma activation time. The conidium germination ratios of $F$. graminearum treated with PAW60 and PAW45 were significantly different from that of control $(P<0.01)$. Conversely, the conidium germination ratios of $F$. graminearum treated with PAW30 and PAW15 were not significantly different from the control. The results were consistent with the mycelium growth and conidiation assay findings. The inhibitory effect of PAW was time-specific and increased over activation time.

Conidiation was measured after 7 days of culture on CM supplemented with $100 \mathrm{mg} \mathrm{L}^{-1}$ or $200 \mathrm{mg}$ $\mathrm{L}^{-1}$ Congo red and $50 \mathrm{mg} \mathrm{L}^{-1}$ Calcofluor White. As shown in Fig. 3e, the conidial production of PAW treated strains was significantly $(P<0.05)$ reduced compared to that of the nontreated strains after 7 days of incubation. All the groups exhibited suppression of conidiation. The inhibitory effect increased over the plasma activation time. PAW60 had the greatest inhibitory effect on the conidiation of $F$. graminearum, and PAW15 had a weaker inhibitory effect on the conidiation than the other PAW treatment. The results demonstrate that PAW could effectively suppress conidiation.

The total microbial activity of the spores was estimated through the fluorescein diacetate (FDA) method. As shown in Fig. 4c, PAW-treated spores exhibited a decreased proportion of green fluorescence, suggesting a decrease in the total microbial activity of spores after PAW treatments. This result was in line with in vitro fungicidal activity assay. 

that biological reactive substances such as ROS and RNS in PAW or cold plasma act synergistically in microbial inactivation (Ercan et al., 2013; Los et al., 2020; Ma et al., 2015; Puligundla et al., 2018; Š imončicová et al., 2018). The fungal cell wall and plasma membrane are the first cell structures that glucose, (N-acetyl)-glucosamine, glycoproteins and glucan in the cell wall and lipid peroxidation in the plasma membrane, causing membrane permeability changes, membrane damage, surface sculpturing in cell wall, and eventually the direct exposure of intracellular components to reactive species. The SEM and TEM results showed that spore cell wall and membrane sculpturing occurred after PAW treatment (Fig. 4), supporting this hypothesis.

cause significant acidification of the intracellular environment. Disruption of intracellular $\mathrm{pH}$ results indicated that acidification of the intracellular environment is mainly attributed to cell wall graminearum cells through damaged cell membranes.

\subsection{Effect of PAW on cell morphology and cell membrane integrity}


and PAW60. The results from SEM and TEM observations in this study showed that PAW could cause the surface sculpturing in the cell walls of spores, which may be attributed to the oxidative damage induced by reactive species in PAW (Puligundla et al., 2018; Timoshkin et al., 2012; Xu et al., 2020). It is generally agreed that ROS can lead to cell wall damage (Lu, et al., 2017; Shen et al., 2016; Xiang et al., 2018; $\mathrm{Xu}$ et al., 2020). The composition of the cell wall, which includes glucose, (N-acetyl)glucosamine, glycoproteins and glucan, can be oxidized by these reactive species.

The cell membrane is an important organelle that maintains normal cell physiological metabolism. In addition to cell wall damage, reactive species can cause changes in membrane permeability (Gaunt et al., 2006). In this study, the FDA staining method and the DNA/RNA and protein leakage method were employed to assess the effect of PAW on cell membrane integrity (Xiang et al., 2019a; Xu et al., 2020). FDA easily entered the cell membranes and was cleaved by the enzymatic activity of nonspecific esterase and, hence, was detected within live cells, and its fluorescence depends on cell membrane integrity (Grimm et al., 2013; Jones et al., 2016). The decreased proportion of green fluorescence indicated a defect in cell membrane integrity (Fig. 4c).

The leakage of intracellular DNA/RNA and proteins was also a significant indicator of the disruption of cell membrane integrity. As shown in Table 1, upon the addition of PAW to F. graminearum spores, there were no significant differences in absorbance $(260 \mathrm{~nm}$ and $280 \mathrm{~nm})$ in any of the treatment groups compared with the control. Our results indicated that there was no leakage of DNA, RNA or protein, and the cell membranes of the spores were not severely compromised by PAW.

In previous literature (Xiang et al., 2018; Xiang et al., 2019a), PAW treatment resulted in the leakage of nucleic acids and proteins in Pseudomonas deceptionensis CM2 and Escherichia coli O157:H7, which was not identical to our study, the leakage of intracellular DNA/RNA and proteins was not observed in 
361 this work. The main reasons for this difference are probably attributed to the difference in membrane composition and the different ORP value of PAW. PAW can change the membrane permeability and allow small inorganic molecules such as RONS to enter the spore, but the extent of the change in membrane permeability was not sufficient to induce the leakage of biomacromolecules in this study.

\subsection{Measurement of mitochondrial activity}

The mitochondrial membrane potential $\left(\Delta \psi_{\mathrm{m}}\right)$ is an indicator of mitochondrial membrane integrity, and $\Delta \psi_{\mathrm{m}}$ depolarizes when the membrane is perturbed, consequently combining with less TMRM probe. As shown in et al., 2003). Furthermore, the degree of depolarization of $\Delta \psi_{\mathrm{m}}$ was in line with the ORP of PAW, and analysis of intracellular redox pairs such as NADH/NAD+ and GSH/GSSG indicated a correlation between extracellular ORP and intracellular redox homeostasis (Li et al., 2019). The existing literatures suggest that a significant increase of intracellular ROS could be induced by PAW (Ma et al., 2013; Tian et al., 2015; Xu et al., 2020). Based on these results, it is hypothesized that extracellular ORP leads to the accumulation of intracellular ROS, and ROS induce the opening of the mitochondrial permeability 
bioRxiv preprint doi: https://doi org/10.1101/2021.07.15.452455; this version posted July 15,2021 . The copyright holder for this preprint (which was not certified by peer review) is the author/funder, who has granted bioRxiv a license to display the preprint in perpetuity. It is made available under aCC-BY 4.0 International license.

\subsection{Overview of changes in gene expression of $F$. graminearum in response to PAW treatment}

The numbers of clean reads for PAW-treated and untreated samples were $42,916,050 \pm 830015$ and 39,063,536 $\pm 918,515$, respectively. The indicator Q30 value for PAW-treated and untreated samples were $94.15 \pm 0.15 \%$ and $94.37 \pm 0.07 \%$, respectively. Uniquely mapped reads in the PAW-treated and -untreated libraries matched $82.49 \pm 1.88 \%$ and $87.20 \pm 1.76 \%$ of the total reads, respectively.

\subsection{Differential gene expression analysis of F. graminearum strain PH-1 treated with PAW}

Mapping of the raw RNA-seq expression data revealed that a total of $2837(22 \%)$ of the $12,792 \mathrm{~F}$. graminearum unigenes were differentially regulated by PAW treatment. The thresholds for differential expression were $P$ adjusted $<0.001$ and expression fold Change $>5$ for up- and downregulated genes. By these criteria, we identified 703 genes upregulated and 676 genes downregulated by PAW. As shown in Fig. 6, of the 1379 genes, 944 genes were classified as having "unknown function”.

There were 3 putative genes (FGSG_10140, FGSG_04852, and FGSG_09329) involved in mitochondrial function in the 10 most upregulated genes and 1 gene (FGSG_03959) involved in the cell membrane in the top 5 downregulated genes in response to PAW. The results indicated that the cell membrane and mitochondria were the organelles most affected by PAW. Based on the results of this report and previous literatures, we mainly focused on the genes involved in mitochondrial function and cell wall and membrane integrity (Liu et al., 2010; Suwal et al., 2019; Los et al., 2020; Xu et al., 2020).

The most upregulated gene involved in mitochondrial function is listed in Table 3 . The differences in gene expression of treated PH-1 ranged from up to a 3662.08-fold increase to a 11.35 -fold increase compared to untreated PH-1. The most upregulated gene was FGSG_10140, and the putative product encoded by the gene is succinate dehydrogenase assembly factor. It is well known that succinate 
401 dehydrogenase (complex II; or succinate: ubiquinone oxidoreductase, SQR) is a functional member of the aerobic respiratory chain. Complex II couples the oxidation of succinate to fumarate in the mitochondrial matrix with the reduction of ubiquinone in the membrane (Yankovskaya et al., 2003). It

was found that the SQR redox centers are arranged in a manner that aids the prevention of ROS formation at the flavin adenine dinucleotide. This is likely to be the main reason FGSG_10140 and other genes are highly expressed during PAW treatment, which can induce high intracellular ROS levels. 0.00049-fold decrease compared to untreated PH-1. The most upregulated gene was FGSG_02821, and the putative product encoded by the gene is a transmembrane protein that belongs to the HPP family according to NCBI BLAST analysis. These proteins are integral membrane proteins. While the function of these proteins is uncertain, they may be transporters. It has been shown that the HPP family of integral membrane proteins transports nitrite across the chloroplast membrane (Krapp, 2015; Maeda et al., 2014). In addition, nitrate and nitrite exist in PAW generated by air plasma. Based on these results, it is in PAW.

The most downregulated gene was FGSG_03959, and the putative product encoded by the gene was protein PTH11 according to NCBI BLAST analysis. PTH11 has been shown to be important for appressorium formation and pathogenicity in Magnaporthe grisea (DeZwaan et al. 1999; Kou et al., 2016). In addition, 30 genes were detected during infection of three hosts (wheat, barley, and maize) encoding G-protein coupled receptors (GPCRs) belonging to the integral membrane protein PTH11 class, 
1,11 of the 30 genes showed differential expression during PAW treatment in our work, and 7 of the 11 genes were downregulated genes. Deletion of these downregulated genes resulted in a significant reduction in conidiation, confirming the result that PAW treatment reduces the conidiation of $F$. graminearum. However, the most downregulated gene, FGSG_03959, showed no or barely detectable expression in hyphae, perithecia and infected wheat heads during infection, indicating that the gene is probably not essential for plant infection (Jiang et al., 2019).

\subsection{Validation of the differential expression results}

related genes, thirteen PH-1 unigenes were selected for further analysis on the basis of their expression levels and possible roles in defense mechanisms in response to PAW (Table 2). As shown in Table 5, in general, the Q-PCR results correlated with the transcriptomic data. However, the fold changes in expression determined by DESeq2 sequencing were not in line with those determined by Q-PCR. We observed that the expression levels of FGSG_10140, FGSG_04852, FGSG_09329, FGSG_06167, FGSG_08435, FGSG_05863 and FGSG_02821 determined by DESeq2 analysis were much higher than those determined by Q-PCR. The possible reason for these discrepancies is that the precision and accuracy of the methods are different.

\section{Conclusion}

In conclusion, the results from our study confirmed that PAW treatment is a highly effective disinfection procedure against $F$. graminearum. It has the potential to control fungal contamination. This study also unravels the potential antifungal mechanism of PAW from the perspective of cellular response 
443

and differential gene expression. ROS and RNS in PAW first compromised the cell membrane, leading to intracellular ROS accumulation, and then intracellular $\mathrm{pH}$ decreased, and depolarization of $\Delta \psi_{\mathrm{m}}$ and mitochondria dysfunction occurred. The DESeq2 sequencing analysis enhanced the hypothesis by the fact that there were three putative genes involved in mitochondrial function in the 10 most upregulated genes and one gene involved in the cell membrane in the top 5 downregulated genes in response to PAW treatment. The information obtained from this work may verify the feasibility and validity of the application of this technique in plant disease control and provides important insights into the antifungal mechanism of PAW to fight against $F$. graminearum.

\section{Declaration of Competing Interest:}

The authors declare no conflict of interest in this paper.

\section{Acknowledgment}

The authors gratefully acknowledge the financial support provided by the National Natural Science Foundation of China [grant number 31900126 to L. Li and 31701723 to J. Guo]; Zhejiang key research and development program [grant number 2018C02G2011099]; and Program of Innovative Entrepreneurship Training for Undergraduate of Zhejiang A \& F University [grant number 2020KX0002, 2020KX0025].

\section{References}

Beyer, M., Röding, S., Ludewig, A., andVerreet J.A., 2004. Germination and survival of Fusarium graminearum macroconidia as affected by environmental factors. J. Phytopathol. 152, 92-97. https://doi.org/10.1111/j.1439-0434.2003.00807.x. 
bioRxiv preprint doi: https://doi org/10.1101/2021.07.15.452455; this version posted July 15,2021 . The copyright holder for this preprint

(which was not certified by peer review) is the author/funder, who has granted bioRxiv a license to display the preprint in perpetuity. It is made available under aCC-BY 4.0 International license.

463

Bian, C.H., Duan,Y.H., Xiu, Q., Wang, J.Y., Tao, X., Zhou, M.G., 2021. Mechanism of validamycin A inhibiting DON biosynthesis and synergizing with DMI fungicides against Fusarium graminearum. Mol. Plant Pathol. In Press. https://doi.org/10.1111/mpp.13060.

Blandino, M., Minelli, L., Reyneri, A., 2006. Strategies for the chemical control fusarium head blight: effect on yield, alveographic parameters and deoxynivalenol contamination in winter wheat grain. Eur. J.Agron. 25, 193-201. https://doi.org/10.1016/j.eja.2006.05.001.

Brisset, J.L., Benstaali, B., Moussa, D., Fanmoe, J., Njoyim-Tamungang, E., 2011. Acidity control of plasma-chemical oxidation: applications to dye removal, urban waste abatement and microbial inactivation. Plasma Sources Sci. Technol. 20, 034021. https://doi.org/10.1088/0963$\underline{0252 / 20 / 3 / 034021}$

Chandana, L., Sangeetha, C.J., Shashidhar, T., Subrahmanyam, C., 2018. Non-thermal atmospheric pressure plasma jet for the bacterial inactivation in an aqueous medium. Sci. Total Environ. 640, 493-500. https://doi.org/10.1016/j.scitotenv.2018.05.342.

Chen, Y., Yao, K., Wang, K., Xiao, C., Li, K., Khan, B., Zhao, S., Yan, W., Ye, Y., 2020. Bioactiveguided structural optimization of 1,2,3-triazole phenylhydrazones as potential fungicides against Fusarium graminearum. Pestic. Biochem. Phys. 164, 26-32. https://doi.org/10.1016/j.pestbp.2019.12.004.

Cockrell, A. L., Fitzgerald, L. A., Cusick, K. D., Barlow, D. E., Tsoi, S. D., Soto, C. M., Baldwin, J.W., Dale, J.R., Morris, R.C., Little, B.J., Biffinger, J.C., 2017. A comparison of the physical and biochemical properties of Thermus scotoductus SA-01 cultured with microwave radiation and conventional heating. Appl. Environ. Microb. 81, 6285-6293. https://doi.org/10.1128/AEM.01618$\underline{15}$. 
bioRxiv preprint doi: https://doi org/10.1101/2021.07.15.452455; this version posted July 15,2021 . The copyright holder for this preprint

(which was not certified by peer review) is the author/funder, who has granted bioRxiv a license to display the preprint in perpetuity. It is made available under aCC-BY 4.0 International license.

485

Collos, Y., Mornet, F., Sciandra, A., Waser, N., Larson, A., Harrison, P.J., 1999. An optical method for the rapid measurement of micromolar concentrations of nitrate in marine phytoplankton cultures. J. Appl.Phycol. 11, 179-184. https://doi.org/10.1023/A:100804602.

D’Angelo, D.L., Bradley, C. A., Ames, K. A., Willyerd, K.T., Madden, L.V., Paul, P. A., 2014 Efficacy of Fungicide Applications During and After Anthesis Against Fusarium Head Blight and Deoxynivalenol in Soft Red Winter Wheat. Plant diease, 98, 1387-1397. https://doi.org/10.1094/PDIS-01-14-0091-RE.

Demissie, A.Z., Foote, S.J., Tan, Y.F., Loewen, M.C., 2018 Profiling of the transcriptomic responses of Clonostachys rosea upon treatment with Fusarium graminearum secretome. Front. Microbiol. 9, 1061. https://doi.org/10.3389/fmicb.2018.01061.

Depasquale, D.A., and Montville, T.J., 1990. Mechanism by which ammonium bicarbonate and ammonium sulfate inhibit mycotoxigenic fungi. Appl. Environ. Microbiol. 56, 3711-3717. https://doi.org/10.1002/bit.260361013.

DeZwaan, T.M., Carroll, A.M., Valent, B., Sweigard, J.A., 1999. Magnaporthe grisea Pth11p Is a Novel Plasma Membrane Protein That Mediates Appressorium Differentiation in Response to Inductive Substrate Cues. The Plant cell 11, 2013-2030. https://doi.org/10.1105/tpc.11.10.2013.

Donau, S.S., Bollmann, U.E., Wimmer, R., Bester, K., 2019. Aerobic dissipation of the novel cyanoacrylate fungicide phenamacril in soil and sludge incubations. Chemosphere 233, 873-878. https://doi.org/10.1016/i.chemosphere.2019.06.015.

Ercan, U.K., Wang, H., Ji, H.F., Fridman, G., Brooks, A.D., Joshi, S.G., 2013. Nonequilibrium plasmaactivated antimicrobial solutions are broad-spectrum and retain their efficacies for extended period of time. Plasma Process. Polym. 10, 544-555. https://doi.org/10.1002/ppap.201200104. 
Etzerodt, T., Gislum, R., Laursen, B.B., Heinrichson, K., Gregersen, P.L., Jorgensen, L.N., Fomsgaard, I.S., 2016. Correlation of deoxynivalenol accumulation in Fusarium-infected winter and spring wheat cultivars with secondary metabolites at different growth stages. J. Agric. Food Chem. 64, 4545-4555. https://doi.org/10.1021/acs.jafc.6b01162.

Gaunt, L.F., Beggs, C.B., Georghiou, G.E., 2006. Bactericidal action of the reactive species produced by gas-discharge nonthermal plasma at atmospheric pressure: a review. IEEE Trans Plasma Sci 34, 1257- 1269. https://doi.org/10.1109/TPS.2006.878381.

Girard, P.M., Arbabian, A., Fleury, M., Bauville, G., Puech, V., Dutreix, M., Sousa, J.S., 2016. Synergistic effect of $\mathrm{H}_{2} \mathrm{O}_{2}$ and $\mathrm{NO}_{2}$ in cell death induced by cold atmospheric He plasma. Sci. Rep. 6, 29098. https://doi.org/10.1038/srep29098.

Gorbanev, Y., Privat-Maldonado, A., Bogaerts, A., 2018. Analysis of short-lived reactive species in plasma-air-water systems: the dos and the do nots. Anal. Chem. 90, 13151-13158. https://doi.org/10.1021/acs.analchem.8b03336.

Grimm, J.B., Heckman, L.M., Lavis, L.D., 2013. The chemistry of small-molecule fluorogenic probes. Prog. Mol. Biol. Transl. 113, 1-34. https://doi.org/10.1016/B978-0-12-386932-6.00001-6.

Guo, J., Huang, K., Wang, X., Lyu, C., Yang, N., Li, Y., Wang, J., 2017. Inactivation of yeast on grapes by plasma-activated water and its effects on quality attributes. J. Food Protect. 80, 225-230. https://doi.org/10.4315/0362-028X.JFP-16-116.

Guo, J., Qin, D., Li, W., Wu, F., Li, L., Liu, X., 2021. Inactivation of Penicillium italicum on kumquat via plasma-activated water and its effects on quality attributes. Int. J. Food Microbiol. 343, 109090. https://doi.org/10.1016/j.ijfoodmicro.2021.109090.

Han, L., Patil, S., Boehm, D., Milosavljevic', V., Cullen, P.J., Bourke, P., 2016. Mechanisms of 
aureus.

Appl.

Environ.

Microbiol.

82

(2), $\quad 450-458$. https://doi.org/10.1128/AEM.02660-15.

Harris, L.J., Balcerzak, M., Johnston, A., Schneiderman, D., Ouellet, T., 2016. Host-preferential

Huang, T., Ding, T., Liu, D., Li J., 2020. Degradation of Carbendazim in Soil: Effect of Sewage Sludge-

Derived Biochars. J. Agric. Food Chem. 68, 3703-3710. https://doi.org/10.1021/acs.jafc.9b07244.

Itooka, K., Takahashi, K., Kimata, Y., Izawa, S., 2018. Cold atmospheric pressure plasma causes protein denaturation and endoplasmic reticulum stress in Saccharomyces cerevisiae. Appl. Microbiol. Biotechnol. 102 (5), 2279-2288. https://doi.org/10.1007/s00253-018-8758-2.

Jiang, C., Cao, S., Wang, Z., Xu, H., Liang, J., Liu, H., Wang, G., Ding, M., Wang, Q., Gong, C., Feng, C., Hao, C., Xu, J., 2019. An expanded subfamily of G-protein-coupled receptor genes in Fusarium graminearum required for wheat infection. Nat. Microbiol. 4, 1582-1591. https://doi.org/10.1038/s41564-019-0468-8.

Jones, K., Kim, D.W., Park, J.S., Khang, C.H. 2016. Live-cell fluorescence imaging to investigate the dynamics of plant cell death during infection by the rice blast fungus Magnaporthe oryzae. BMC Plant Biol. 16, 69. https://doi.org/10.1186/s12870-016-0756-x.

Kaneko, T., Sasaki, S., Takashima, K., Kanzaki, M., 2017. Gas-liquid interfacial plasmas producing reactive species for cell membrane permeabilization. J. Clin. Biochem. Nutr. 60, 3-11. https://doi.org/10.3164/jcbn.16-73. 
551 Kim, S.H., and Vujanovic, V., 2016. Relationship between mycoparasites lifestyles and biocontrol behaviors against Fusarium spp. and mycotoxins production. Appl. Microbiol. Biotechnol. 100,

Kou, Y.J., Tan, Y.H., Ramanujam, R., Naqvi, N.I., 2016. Structure-function analyses of the Pth11 receptor reveal an important role for CFEM motif and redox regulation in rice blast. New Phytol. 24, 330-342. https://doi.org/10.1111/nph.14347.

Krapp, A., 2015. Plant nitrogen assimilation and its regulation: a complex puzzle with missing pieces. Curr. Opin. Plant Biol. 25, 115-122. https://doi.org/10.1016/j.pbi.2015.05.010.

Lagadic-Gossmann, D., Huc, L., Lecureur, V., 2004. Alterations of intracellular pH homeostasis in

Li, B. and Dewey, C.N., 2011. RSEM: accurate transcript quantification from RNA-Seq data with or apoptosis: origins and roles. Cell Death Differ. 11, 953-961. https://doi.org/10.1038/sj.cdd.4401466.

Li, K., Xia, J., Muhammad Mehmood, A., Zhao, X.Q., Liu, C.G., Bai, F.W., 2019. Extracellular redox potential regulation improves yeast tolerance to furfural. Chem. Eng. Sci. 196, 54-63. https://doi.org/10.1016/j.ces.2018.11.059.

Liu, X., Jiang, J.H., Shao, J.F., Yin, Y.N., Ma Z.H., 2010. Gene transcription profiling of Fusarium graminearum treated with an azole fungicide tebuconazole. Appl. Microbiol. Biotechnol. 85, 11051114. https://doi.org/10.1007/s00253-009-2273-4.

Livak, K.J., and Schmittgen, T.D., 2001. Analysis of relative gene expression data using real-time quantitative PCR and the 2- $\Delta \Delta \mathrm{CT}$ method. Methods 25, 402-408. https://doi.org/10.1006/meth.2001.1262.

572 Los, A., Ziuzina, D., Boehm, D., Cullen, P. J., Bourke, P., 2020. Inactivation efficacies and mechanisms 
Lu, P., Boehm, D., Bourke, P., Cullen, P. J., 2017. Achieving reactive species specificity within plasmaactivated water through selective generation using air spark and glow discharges. Plasma Process.Polym. 14, e1600207. https://doi.org/10.1002/ppap.201600207.

Lunov, O., Zablotskii, V., Churpita, O., Jäger, A., Polívka, L., Syková, E., Dejneka, A., Kubinová, Š., 2016. The interplay between biological and physical scenarios of bacterial death induced by nonthermal plasma. Biomaterials 82, 71-83. https://doi.org/10.1016/j.biomaterials.2015.12.027.

Ly, J.D., Grubb, D.R., Lawen, A., 2003. The mitochondrial membrane potential $\left(\Delta \psi_{\mathrm{m}}\right)$ in apoptosis; an update. Apoptosis, 8, 115-128. https://doi.org/10.1023/a:1022945107762.

Lysøe, E., Pasquali, M., Breakspear, A., Kistler, H.C., 2011. The transcription factor FgStuAp influences spore development, pathogenicity, and secondary metabolism in Fusarium graminearum. Mol. Plant Microbe In. 24, 54-67. https://doi:10.1094/MPMI-03-10-0075.

590 Maeda S.I., Konishi M., Yanagisawa S., Omata T., 2014. Nitrite transport activity of a novel HPP family protein conserved in cyanobacteria and chloroplasts. Plant Cell Phys. 55, 1311-1324. design of novel antimicrobial peptides for plant protection. Annu. Rev. Phytopathol. 46, 273-301. 
http://doi.org/10.1146/annurev.phyto.121307.094843.

Masci, S., Laino, P., Janni, M., Botticella, E., Di Carli, M., Benvenuto, E., Danieli, P.P., Lilley, K.S., Lafiandra, D., D’Ovidio, R., 2015. Analysis of quality-related parameters in mature kernels of polygalacturonase inhibiting protein (PGIP) transgenic bread wheat infected with Fusarium graminearum.J. Agric. Food Chem. 63, 3962-3969. http://doi.org/10.1021/jf506003t.

McMullen, M., Jones, R., Gallenberg, D., 1997. Scab of wheat and barley: a re-emerging disease of devastating impact. Plant Dis.81, 1340-1348. https://doi.org/10.1094/PDIS.1997.81.12.1340.

Mcferson, L.L., 1993. Understanding ORPS role in the disinfection process. Water-Eng. Manage. 140, $29-31$.

Natali, M., Kamgang-Youbi, G., Herry, J.M., Bellon-Fontaine, M.N., Brisset, J.L., 2010. Combined effects of long-living chemical species during microbial inactivation using atmospheric plasmatreated water. Appl. Environ. Microbiol. 76, 7662-7664. http://doi.org/10.1128/AEM.01615-10.

Oehmigen, K., Hahnel, M., Brandenburg, R., Wilke, C., Weltmann, K.D., von Woedtke, T., 2010. The role of acidification for antimicrobial activity of atmospheric pressure plasma in liquids. Plasma Process. Polym. 7, 250-257. http://doi.org/10.1002/ppap.200900077.

Patangea, A., Lu, P., Boehm, D., Cullen, P.J., Bourke, P., 2019. Efficacy of cold plasma functionalised water for improving microbiological safety of fresh produce and wash water recycling. Food Microbiol. 84, 103226. https://doi.org/10.1016/j.fm.2019.05.010.

Pavlovich, M.J., Chang, H.W., Sakiyama, Y., Clark, D.S., Graves, D.B., 2013. Ozone correlates with antibacterial effects from indirect air dielectric barrier discharge treatment of water. J. Phys. D: Appl. Phys.46, 145202. https://doi.org/10.1088/0022-3727/46/14/145202.

Puligundla, P., Lee, T., Mok, C., 2018. Effect of intermittent corona discharge plasma treatment for 
Pimentel, D., Acquay, H., Biltonen, M., Rice, P., Silva, M., Nelson, J., Lipner, V., Giordano, S., Horowitz, http://doi.org/10.2307/1311994.

Sarangapani, C., Danaher, M., Tiwari, B., Lu, P., Bourke, P., Cullen, P.J., 2017. Efficacy and mechanistic insights into endocrine disruptor degradation using atmospheric air plasma. Chem. Eng. J. 326, 700-

Semighini, C.P., Murray, N., Harris, S.D., 2008. Inhibition of Fusarium graminearum growth and development by farnesol. FEMS Microbiol. Lett. 279, 259-264. https://doi.org/10.1111/j.1574-

Shen, J., Tian, Y., Li, Y., Ma, R., Zhang, Q., Zhang, J., Fang, J., 2016. Bactericidal effects against $S$. aureus and physicochemical properties of plasma activated water stored at different temperatures. Sci. Rep. 6, 28505. http://doi.org/10.1038/srep28505.

Šimončicová, J., Kaliňáková, B., Kováčik, D., Medvecká, V., Lakatoš, B., Kryštofová, S., Hoppanová, L., Palušková, V., Hudecová, D., Ďurina, P., Zahoranováet, A., 2018. Cold plasma treatment triggers antioxidative defense system and induces changes in hyphal surface and subcellular 
bioRxiv preprint doi: https://doi org/10 1101/2021.07.15.452455; this version posted July 15,2021 . The copyright holder for this preprint

(which was not certified by peer review) is the author/funder, who has granted bioRxiv a license to display the preprint in perpetuity. It is made available under aCC-BY 4.0 International license.

639 Suwal, S., Coronel-Aguileraa, C.P., Auer, J., Applegate, B., Garnerc, A.L., Huang, J., 2019. Mechanism

640

641 characterization of bacterial inactivation of atmospheric air plasma gas and activated water using bioluminescence technology. Innov. Food Sci. Emerg. 53, 18-25. https://doi.org/10.1016/j.ifset.2018.01.007.

Traylor, M.J., Pavlovich, M.J., Karim, S., Hait, P., Sakiyama, Y., Clark, D.S., Graves, D.B., 2011. Longterm antibacterial efficacy of air plasma-activated water. J. Phys. D: Appl. Phys. 44, 472001. http://doi.org/10.1088/0022-3727/44/47/472001.

Tian, Y., Ma, R.N., Zhang, Q., Feng, H.Q., Liang, Y.D., Zhang, J., Fang, J., 2015. Assessment of the physicochemical properties and biological effects of water activated by non-thermal plasma above and beneath the water surface. Plasma Process. Polym. 12, 439-449. http://doi.org/10.1002/ppap.201400082.

Timoshkin, I.V., Maclean, M., Wilson, M.P., Given, M.J., MacGregor, S.J., Wang, T., Anderson, J.G., 2012. Bactericidal effect of corona discharges in atmospheric air. IEEE Trans. Plasma Sci.40, 2322-2333. http://doi.org/10.1109/TPS.2012.2193621.

Wiebe, M.G., Robson, G.D., Oliver, S.G., Trinci, A.P.J., 1996. pH oscillations and constant low pH delay the appearance of highly branched (colonial) mutants in chemostat cultures of the quorn ${ }^{\circledR}$ myco protein fungus, Fusarium graminearum A3/5. Biotechnol. Bioeng. 51, 61-68. https://doi.org/10.1002/(SICI)1097-0290(19960705)51:1<61::AID-BIT7>3.0.CO;2-Z.

Xiang, Q., Kang, C., Niu, L., Zhao, D., Li, K., Bai, Y., 2018. Antibacterial activity and a membrane damage mechanism of plasma activated water against Pseudomonas deceptionensis CM2. LWTFood Sci. Technol. 96, 395-401. http://doi.org/10.1016/j.lwt.2018.05.059.

Xiang, Q., Kang, C., Zhao, D., Niu, L., Liu, X., Bai, Y., 2019a. Influence of organic matters on the 
bioRxiv preprint doi: https://doi org/10.1101/2021.07.15.452455; this version posted July 15,2021 . The copyright holder for this preprint

(which was not certified by peer review) is the author/funder, who has granted bioRxiv a license to display the preprint in perpetuity. It is made available under aCC-BY 4.0 International license.

661

662

663

664

665

666

667

668

669

670

671

673

674

inactivation efficacy of plasma-activated water against E. coli $\mathrm{O} 157: \mathrm{H} 7$ and S. aureus. Food Control, 99, 28-33. https://doi.org/10.1016/j.foodcont.2018.12.019.

Xiang, Q., Wang, W., Zhao, D., Niu, L., Li, K. Bai, Y., 2019b. Synergistic inactivation of Escherichia coli $\mathrm{O} 157: \mathrm{H} 7$ by plasma-activated water and mild heat. Food Control, 106, 106741. https://doi.org/10.1016/j.foodcont.2019.106741.

Xu, Y., Tian, Y., Ma, R., Liu, Q., Zhang, J., 2016. Effect of plasma activated water on the postharvest quality of button mushrooms, Agaricus bisporus. Food Chem. 197, 436-444. http://doi.org/10.1016/j.foodchem.2015.10.144.

Xu, H., Ma, R., Zhu, M., Du, M., Zhang, H., Jiao, Z., 2020. A systematic study of the antimicrobial mechanisms of cold atmospheric-pressure plasma for water disinfection. Sci. Total Environ. 703, 134965. https://doi.org/10.1016/j.scitotenv.2019.134965.

Yankovskaya, V., Horsefield, R., Tornroth, S., Luna-Chavez, C., Miyoshi, H., Leger, C., Byrne, B., Cecchini, G., Lwata, S., 2003 Architecture of Succinate Dehydrogenase and Reactive Oxygen Species Generation. Science 299, 700-704. https://doi.org/10.1126/science.1079605.

Zhang, Q., Liang, Y.D., Feng, H.Q., Ma, R.N., Tian, Y., Zhang, J., Fang, J., 2013. A study of oxidative stress induced by non-thermal plasma-activated water for bacterial damage. Appl. Phys. Lett.102, 203701. http://doi.org/10.1063/1.4807133.

Zhang, Q., Ma, R., Tian, Y., Su, B., Wang, K., Yu, S., Zhang, J., Fang, J., 2016. Sterilization efficiency of a novel electrochemical disinfectant against Staphylococcus aureus. Environ. Sci. Technol. 50, 3184-3192. http://doi.org/10.1021/acs.est.5b05108.

Zhou, Z.H., Duan, Y.B., Zhang, J., Lu, F., Zhu, Y.Y., Shim, W.B., Zhou, M.G., 2021. Microtubuleassisted mechanism for toxisome assembly in Fusarium graminearum. Mol. Plant Pathol. 22, 163- 
bioRxiv preprint doi: https://doi.org/10.1101/2021.07.15.452455; this version posted July 15, 2021. The copyright holder for this preprint

(which was not certified by peer review) is the author/funder, who has granted bioRxiv a license to display the preprint in perpetuity. It is made available under aCC-BY 4.0 International license. 
bioRxiv preprint doi: https://doi.org/10.1101/2021.07 15.452455; this version posted July 15, 2021. The copyright holder for this preprint (which was not certified by peer review) is the author/funder, who has granted bioRxiv a license to display the preprint in perpetuity. It is made available under aCC-BY 4.0 International license.

687 Table 1 Release of intracellular nucleic acids and protein from spores treated with PAW.

\begin{tabular}{llllll}
\hline Absorbance & Control & PAW15 & PAW30 & PAW45 & PAW60 \\
\hline $260 \mathrm{~nm}$ & $0.098 \pm 0.003 \mathrm{a}$ & $0.098 \pm 0.002 \mathrm{a}$ & $0.095 \pm 0.006 \mathrm{a}$ & $0.086 \pm 0.004 \mathrm{~b}$ & $0.087 \pm 0.003 \mathrm{~b}$ \\
$280 \mathrm{~nm}$ & $0.054 \pm 0.002 \mathrm{a}$ & $0.051 \pm 0.007 \mathrm{a}$ & $0.043 \pm 0.003 \mathrm{a}$ & $0.043 \pm 0.005 \mathrm{a}$ & $0.044 \pm 0.004 \mathrm{a}$ \\
\hline
\end{tabular}

688 The results are expressed as the means \pm standard deviations $(\mathrm{n}=6)$. Values with different letters in the

689 same row are significantly different $(P<0.05)$.

690 
bioRxiv preprint doi: https://doi.org/10.1101/2021.07.15.452455. this version posted July 15.2021 . The copyriaht holder for this preprin (which was not certified by peer review) is the author/funder, who has granted bioRxiv a license to display the preprint in perpetuity. It is made available under aCC-BY 4.0 International license.

691 Table 2 A list of primers used in real-time PCR analysis

\begin{tabular}{|c|c|}
\hline Target gene & Primer sequence $\left(5^{\prime}-3^{\prime}\right)$ \\
\hline \multirow[t]{2}{*}{ FGSG_10140 } & FGSG_10140-F1: ACCCCTCTCCACAACCGTTTCAC \\
\hline & FGSG_10140-R1: GACTGGTAGACAAGGCGGGCTCG \\
\hline \multirow[t]{2}{*}{ FGSG_04852 } & FGSG_04852-F1: CGGCGATGGTGACAAGACTGAAG \\
\hline & FGSG_04852-R1: ATGCTGGCGTCTTGACTGATTTC \\
\hline \multirow[t]{2}{*}{ FGSG_09329 } & FGSG_09329-F1: GATACCGATTTCCAGAAGAGCGT \\
\hline & FGSG_09329-R1: GAACCAGGAGGACCAAGCACAGC \\
\hline \multirow[t]{2}{*}{ FGSG_06167 } & FGSG_06167-F1: CGCAAAACGAAGGACAACAACCC \\
\hline & FGSG_06167-R1: GGCTTCGGTAGTGGGATGTTTGA \\
\hline \multirow[t]{2}{*}{ FGSG_08435 } & FGSG_08435-F1: CTGTCGCACCCTCACCAAGAACC \\
\hline & FGSG_08435-R1: GATGACGGGTCCAGGCGAGTTAC \\
\hline \multirow[t]{2}{*}{ FGSG_05863 } & FGSG_05863-F2: CTGTGTGGTCTTTGATGCGTGGA \\
\hline & FGSG_05863-R2: TCCGATGGGGTGTGCTCTTCTTC \\
\hline \multirow[t]{2}{*}{ FGSG_07299 } & FGSG_07299-F2: CGAATGTGACGACAAAAGATGGA \\
\hline & FGSG_07299-R2: CATCAACCTCAATCAAATACGCC \\
\hline \multirow[t]{2}{*}{ FGSG_01743 } & FGSG_01743-F2: CGACACTGTTCTGATTGACCCCG \\
\hline & FGSG_01743-R2: CCAGTGAAGTAGTATCCAGGGTA \\
\hline \multirow[t]{2}{*}{ FGSG_05401 } & FGSG_05401-F1: TACGGATACCGCACATCTTTGGA \\
\hline & FGSG_05401-R1: GCCCATCCTTTGGTAAACCCCGT \\
\hline \multirow[t]{2}{*}{ FGSG_02821 } & FGSG_02821-F1: TCATCAATCCCTTCATTCCACCG \\
\hline & FGSG_02821-R1:GAAGGTATGCGTTCTGAAGCCAA \\
\hline \multirow[t]{2}{*}{ FGSG_09830 } & FGSG_09830-F1: AAGATGGCTCTCCAAATCGCTAT \\
\hline & FGSG_09830-R1: CGAGACCGAAAGGAGCGGAGTAG \\
\hline \multirow[t]{2}{*}{ FGSG_04144 } & FGSG_04144-F2: TCAAGTCCATTCCAAAGGTCATC \\
\hline & FGSG_04144-R2: ACCATTCTTTGGCAGTTCTCGTA \\
\hline \multirow[t]{2}{*}{ FGSG_03959 } & FGSG_03959-F1: TCATCGTGTCATTTTGCTTCGGT \\
\hline & FGSG_03959-R1: ATGTCATCTTGAATGTCTTGGGC \\
\hline \multirow[t]{2}{*}{ FGSG_07335 (Actin) } & Actin-F ATCCACGTCACCACTTTCAA \\
\hline & Actin-R TGCTTGGAGATCCACATTTG \\
\hline
\end{tabular}

692 
693 Table 3 Response to PAW of the genes involved in mitochondrial function

\begin{tabular}{|c|c|c|c|}
\hline Accession number & Putative product encoded by the gene & $\begin{array}{l}\text { Fold change in gene } \\
\text { expression }^{\mathrm{a}}\end{array}$ & Padjust \\
\hline FGSG_10140 & $\begin{array}{l}\text { Hypothetical protein similar to } \\
\text { succinate dehydrogenase assembly } \\
\text { factor } 2 \text {, mitochondrial }\end{array}$ & 3662.08 & $<0.001$ \\
\hline FGSG_04852 & $\begin{array}{l}\text { Hypothetical protein similar to } \\
\text { NADH-cytochrome b5 reductase }\end{array}$ & 2195.27 & $<0.001$ \\
\hline FGSG_09329 & $\begin{array}{l}\text { Hypothetical protein similar to } \\
\text { ATPase }\end{array}$ & 2122.66 & $<0.001$ \\
\hline FGSG_06167 & $\begin{array}{l}\text { Hypothetical protein similar to } 54 \mathrm{~s} \\
\text { ribosomal protein } \mathrm{L} 4 \text {, mitochondrial }\end{array}$ & 839.12 & $<0.001$ \\
\hline FGSG_08435 & $\begin{array}{l}\text { Hypothetical protein similar to } \\
\text { nitronate monooxygenase }\end{array}$ & 783.80 & $<0.001$ \\
\hline FGSG_05863 & Mitochondrial import protein 1 & 714.07 & $<0.001$ \\
\hline FGSG_07299 & $\begin{array}{l}\text { Hypothetical protein similar to } \\
\text { transferase CAF } 17 \text {, mitochondrial }\end{array}$ & 37.54 & $<0.001$ \\
\hline FGSG_01743 & Acetyl-coenzyme A synthetase & 11.35 & $<0.001$ \\
\hline
\end{tabular}


697 Table 4 Response to PAW of the genes involved in cell wall and membrane integrity

\begin{tabular}{|c|c|c|c|}
\hline $\begin{array}{l}\text { Accession } \\
\text { number }\end{array}$ & Putative product encoded by the gene & $\begin{array}{l}\text { Fold change in gene } \\
\text { expression }^{\mathrm{a}}\end{array}$ & Padjust \\
\hline FGSG_02821 & $\begin{array}{l}\text { Hypothetical protein similar to } \\
\text { transmembrane protein }\end{array}$ & 1731.37 & $<0.001$ \\
\hline FGSG_04144 & $\begin{array}{l}\text { Hypothetical protein similar to vi } \\
\text { polysaccharide biosynthesis vipa tvib }\end{array}$ & 47.51 & $<0.01$ \\
\hline FGSG_05401 & $\begin{array}{l}\text { Hypothetical protein similar to Beta-1,3- } \\
\text { glucanase }\end{array}$ & 12.46 & $<0.001$ \\
\hline FGSG_09830 & C-4 methylsterol oxidase & 9.60 & $<0.001$ \\
\hline FGSG_03959 & $\begin{array}{l}\text { Hypothetical protein similar to plasma } \\
\text { membrane protein pth } 11\end{array}$ & 0.00049 & $<0.001$ \\
\hline
\end{tabular}

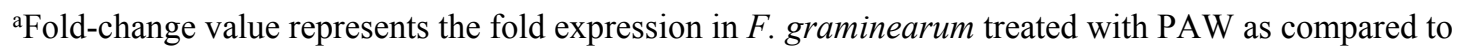

699 that in nontreatment control 
701 Table 5 Comparison in the changes of gene expression determined by DESeq2 sequencing and real-time

702 PCR approaches

\begin{tabular}{|c|c|c|c|}
\hline $\begin{array}{l}\text { Accession } \\
\text { number }\end{array}$ & Putative product encoded by the gene & $\begin{array}{l}\text { Fold change in gene } \\
\text { expression determined } \\
\text { by DESeq2 sequencing }^{\mathrm{a}}\end{array}$ & $\begin{array}{l}\text { Fold change in } \\
\text { gene expression } \\
\text { determined by } \\
\text { real-time PCR }\end{array}$ \\
\hline FGSG_10140 & $\begin{array}{l}\text { Hypothetical protein similar to succinate } \\
\text { dehydrogenase assembly factor } 2, \\
\text { mitochondrial }\end{array}$ & 3662.08 & 52.83 \\
\hline FGSG_04852 & $\begin{array}{l}\text { Hypothetical protein similar to NADH- } \\
\text { cytochrome b5 reductase }\end{array}$ & 2195.27 & 40.41 \\
\hline FGSG_09329 & Hypothetical protein similar to ATPase & 2122.66 & 2.52 \\
\hline FGSG_06167 & $\begin{array}{l}\text { Hypothetical protein similar to } 54 \mathrm{~s} \\
\text { ribosomal protein } \mathrm{L} 4 \text {, mitochondrial }\end{array}$ & 839.12 & 14.32 \\
\hline FGSG_08435 & $\begin{array}{l}\text { Hypothetical protein similar to nitronate } \\
\text { monooxygenase }\end{array}$ & 783.80 & 22.12 \\
\hline FGSG_05863 & Mitochondrial import protein 1 & 714.07 & 12.64 \\
\hline FGSG_07299 & $\begin{array}{l}\text { Hypothetical protein similar to } \\
\text { transferase CAF } 17 \text {, mitochondrial }\end{array}$ & 37.54 & 2.18 \\
\hline FGSG_01743 & Acetyl-coenzyme A synthetase & 11.35 & 19.47 \\
\hline FGSG_02821 & $\begin{array}{l}\text { Hypothetical protein similar to } \\
\text { transmembrane protein }\end{array}$ & 1731.37 & 7.95 \\
\hline FGSG_04144 & $\begin{array}{l}\text { Hypothetical protein similar to vi } \\
\text { polysaccharide biosynthesis vipa tvib }\end{array}$ & 47.51 & 7.13 \\
\hline FGSG_05401 & $\begin{array}{l}\text { Hypothetical protein similar to Beta-1,3- } \\
\text { glucanase }\end{array}$ & 12.46 & 10.90 \\
\hline FGSG_09830 & C-4 methylsterol oxidase & 9.60 & 13.48 \\
\hline FGSG_03959 & $\begin{array}{l}\text { Hypothetical protein similar to plasma } \\
\text { membrane protein pth } 11\end{array}$ & 0.00049 & 0.080 \\
\hline
\end{tabular}




\section{Figure captions}

Fig. 1 Physicochemical properties of PAW: a) Concentrations of nitrate anions $\left(\mathrm{NO}_{3}^{-}\right)(\square)$ and nitrite anions $\left(\mathrm{NO}_{2}^{-}\right)(\triangle)$ in PAW. b) ORP value of PAW subjected to plasma activation for $0,15,30,45$, and 60 min. c) $\mathrm{pH}$ value of PAW subjected to plasma activation for $0,15,30,45$, and $60 \mathrm{~min}$. d) Conductivity of PAW subjected to plasma activation for $0,15,30,45$, and $60 \mathrm{~min}$. The results represent the mean \pm standard deviation $(n=3)$. Vertical bars represent standard deviation of the mean, columns with different letters represent statistically significant results $(P<0.05)$.

Fig. 2 Disease severity indexes are the mean area of disease divided by the total area of the wheat $\times$ $100 \%$. Groups of bars followed by the same letter are not significantly different according to Fisher's protected least significant difference $(P<0.05)$.

Fig. 3 a) Representative image of the colony morphology of $F$. graminearum exposed to PAW15, PAW30, PAW45, and PAW60 treatment for 1h; an image was obtained every $12 \mathrm{~h}$ after treatment with PAW during 5 days of incubation at $28^{\circ} \mathrm{C}$. b) Dry mycelial weight after PAW treatment cultured in CM supplemented with $100 \mathrm{mg} \mathrm{L}^{-1}, 200 \mathrm{mg} \mathrm{L}^{-1}$ Congo red and $50 \mathrm{mg} \mathrm{L}^{-1}$ Calcofluor White. c) Inhibition ratio of mycelium growth after treatment with PAW during 5 days of incubation at $28^{\circ} \mathrm{C}$ on $\mathrm{CM}$ plate. d) Conidium germination ratio and relative conidium germination ratio of $F$. graminearum after treatment with PAW cultured in $\mathrm{CM}$. $\mathrm{R}$ : conidium germination ratio, $\mathrm{R}_{\mathrm{e}}$ : relative conidium germination ratio. e) Conidiation of $F$. graminearum treated with PAW after 7 days culture in CM supplemented with $100 \mathrm{mg} \mathrm{L} \mathrm{L}^{-1}, 200 \mathrm{mg} \mathrm{L}^{-1}$ Congo red and $50 \mathrm{mg} \mathrm{L}^{-1}$ Calcofluor White. The results represent the mean \pm standard deviation $(n=6)$. Vertical bars represent standard deviation of the mean, columns with different letters represent statistically significant results $(P<0.05)$. 
bioRxiv preprint doi: https://doi.org/10.1101/2021.07.15.452455; this version posted July 15, 2021. The copyright holder for this preprint

(which was not certified by peer review) is the author/funder, who has granted bioRxiv a license to display the preprint in perpetuity. It is made available under aCC-BY 4.0 International license.

728 Fig. 4. a) SEM images of spores treated with PAW. b) TEM images of spores treated with PAW. c) The

fluorescence images of $F$. graminearum spores stained by FDA.

730

Fig. 5. The fluorescence images of $F$. graminearum spores stained by TMRM.

731 Fig. 6 COG categories of differentially expressed genes relative to PAW-treated F. graminearum. 
bioRxiv preprint doi: https://doi.org/10.1101/2021.07.15.452455; this version posted July 15, 2021. The copyright holder for this preprint (which was not certified by peer review) is the author/funder, who has granted bioRxiv a license to display the preprint in perpetuity. It is made available under aCC-BY 4.0 International license.

\section{Highlights:}

734 - The viability of F. graminearum is notably inhibited by PAW

- The symptoms caused by $F$. graminearum were significantly reduced on the spikelets

- Oxidative stress induce cell wall sculpturing, membrane permeability change

- PAW can cause the mitochondrial dysfunction

- Cell wall, membrane and mitochondria are the most affected organelles by PAW 
a)

b)

c)
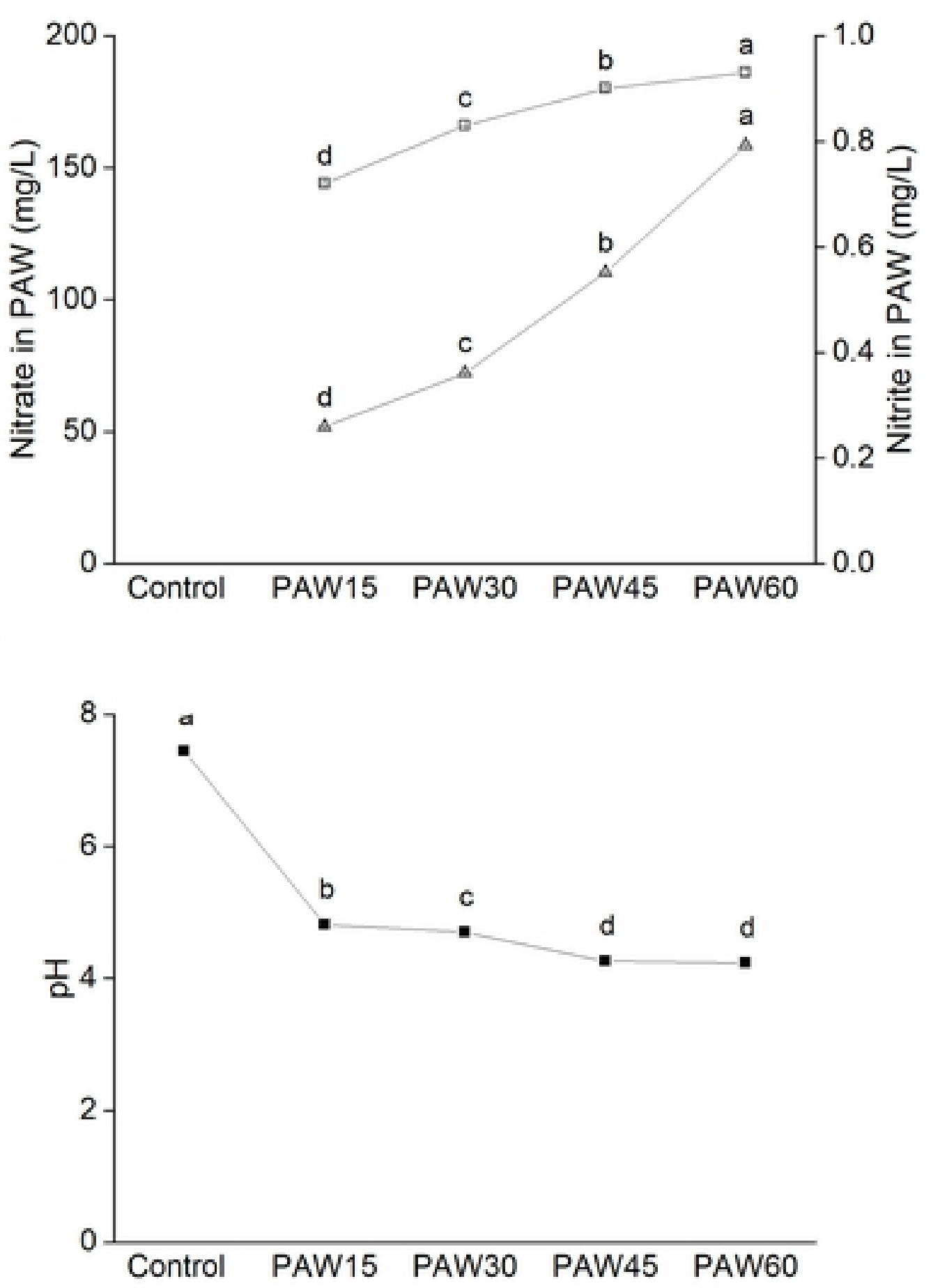



d)

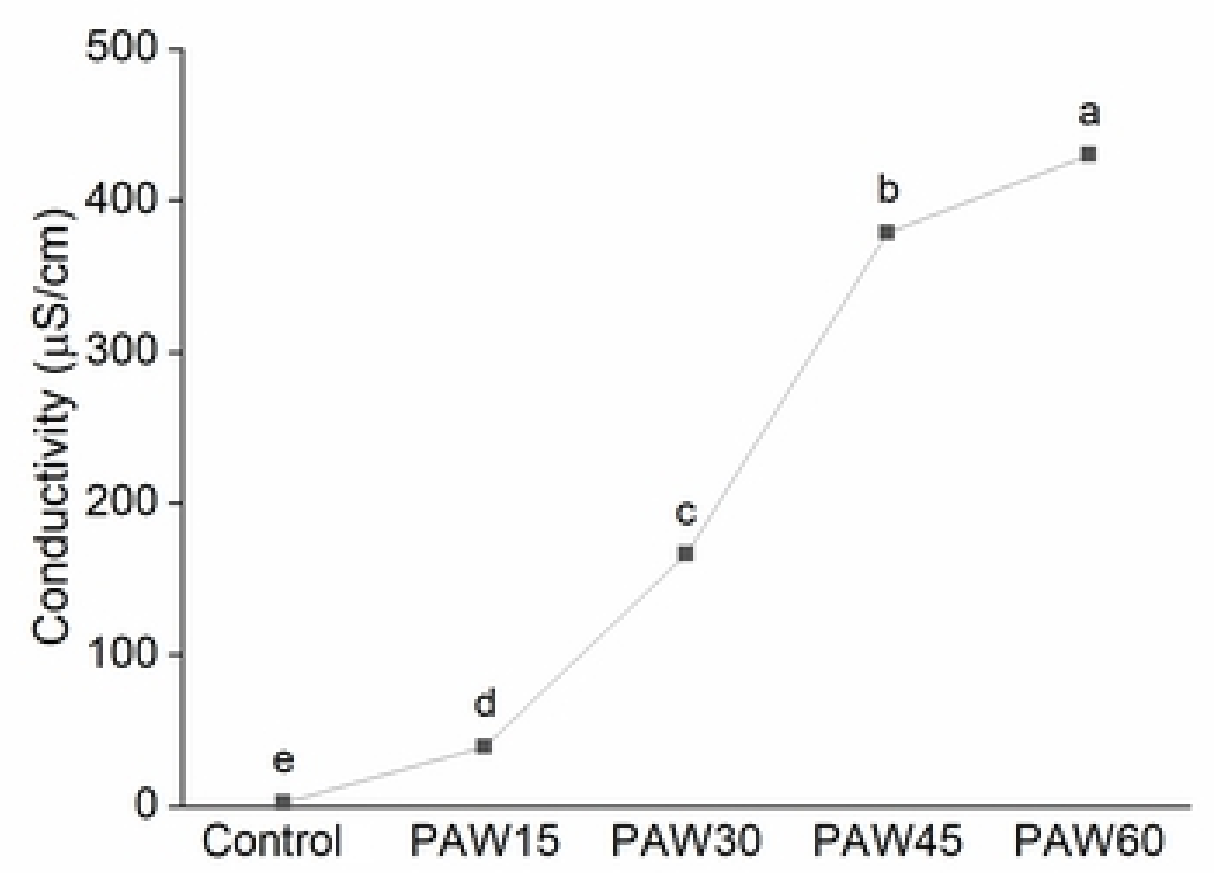

\section{Figure1}




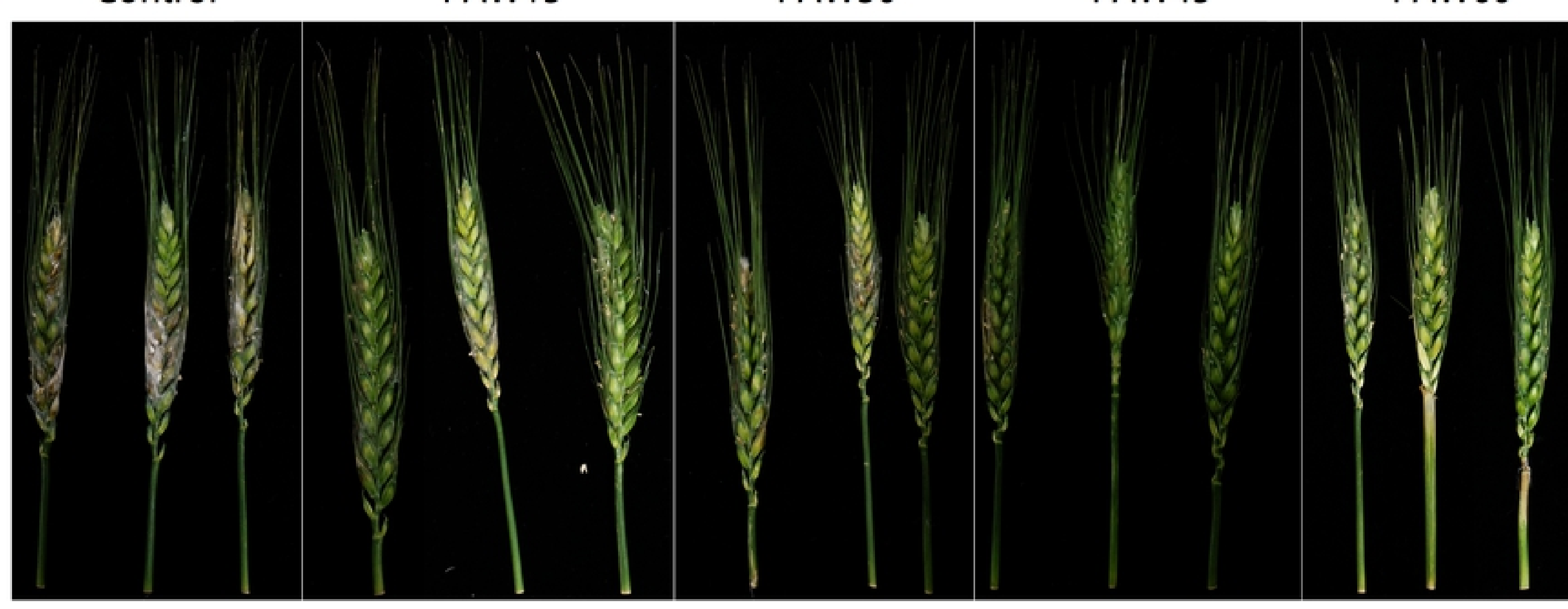

Figure2a 


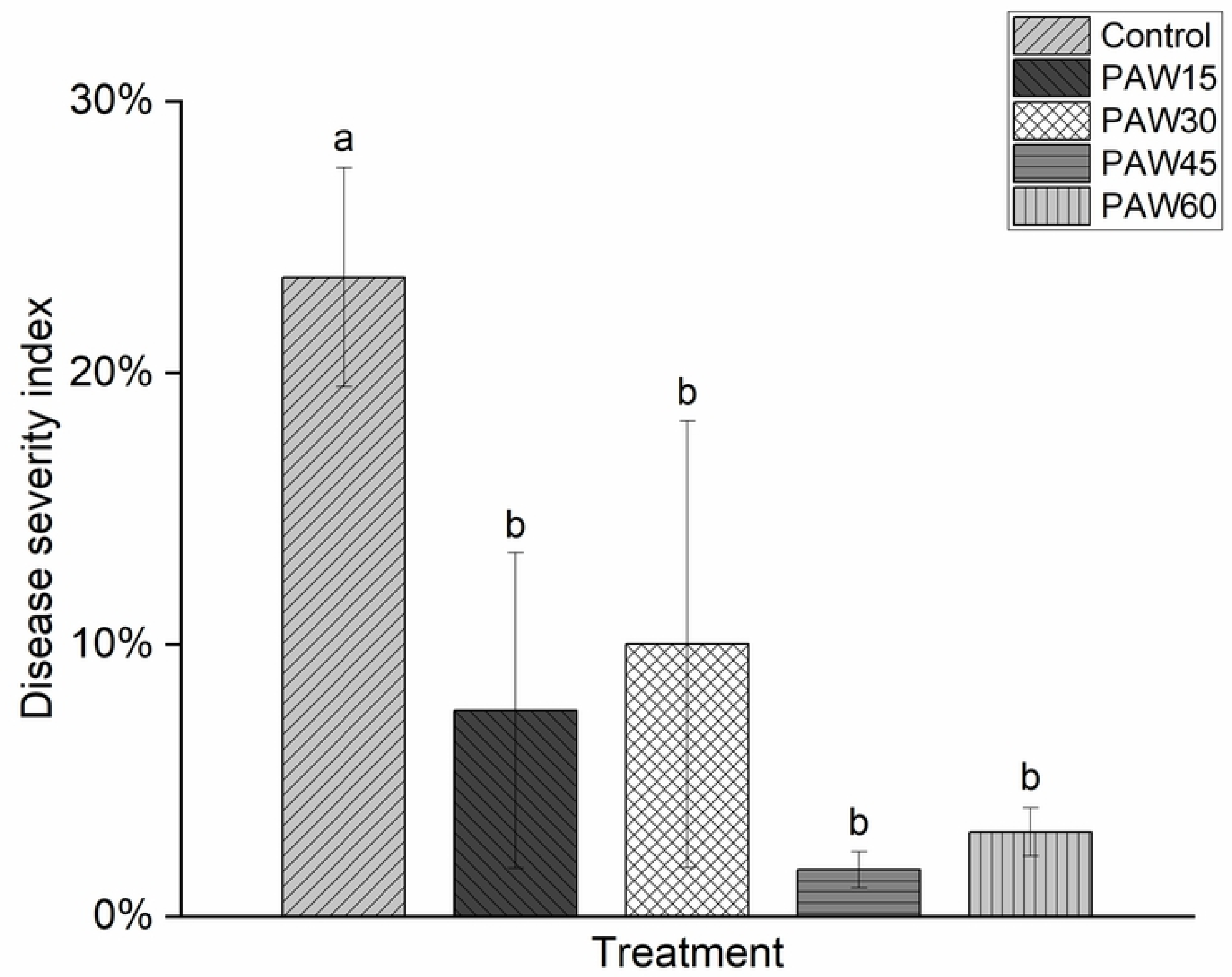

Figure $2 b$ 
a)

$12 \mathrm{~h} \quad 24 \mathrm{~h} \quad 36 \mathrm{~h} \quad 48 \mathrm{~h} \quad 60 \mathrm{~h} \quad 72 \mathrm{~h} \quad 84 \mathrm{~h} \quad 96 \mathrm{~h} \quad 108 \mathrm{~h} \quad 120 \mathrm{~h}$

Control

PAW15

PAW30
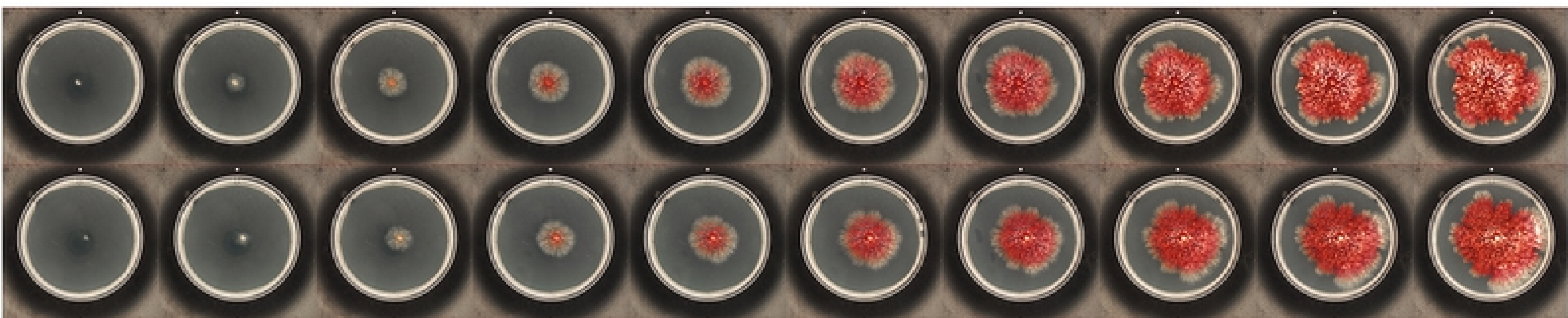

PAW45


PAW60
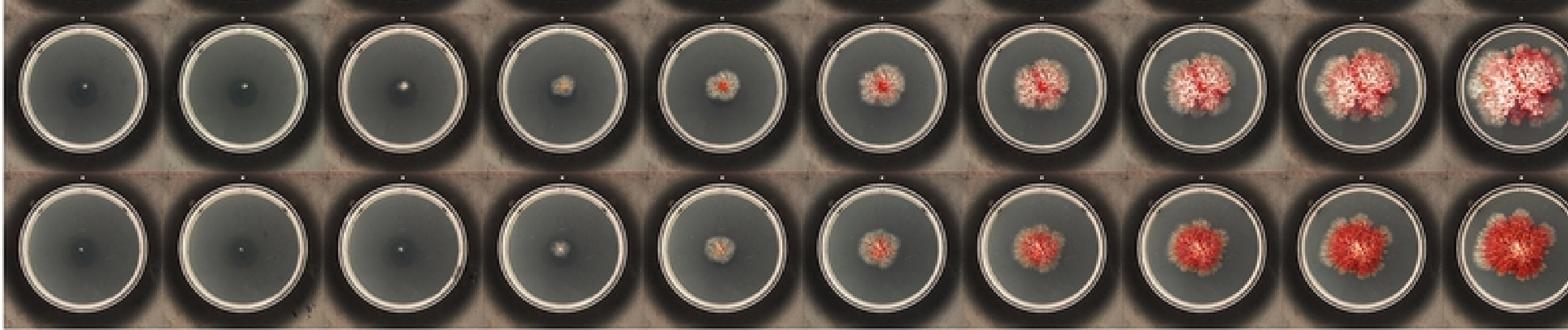

Figure3a 

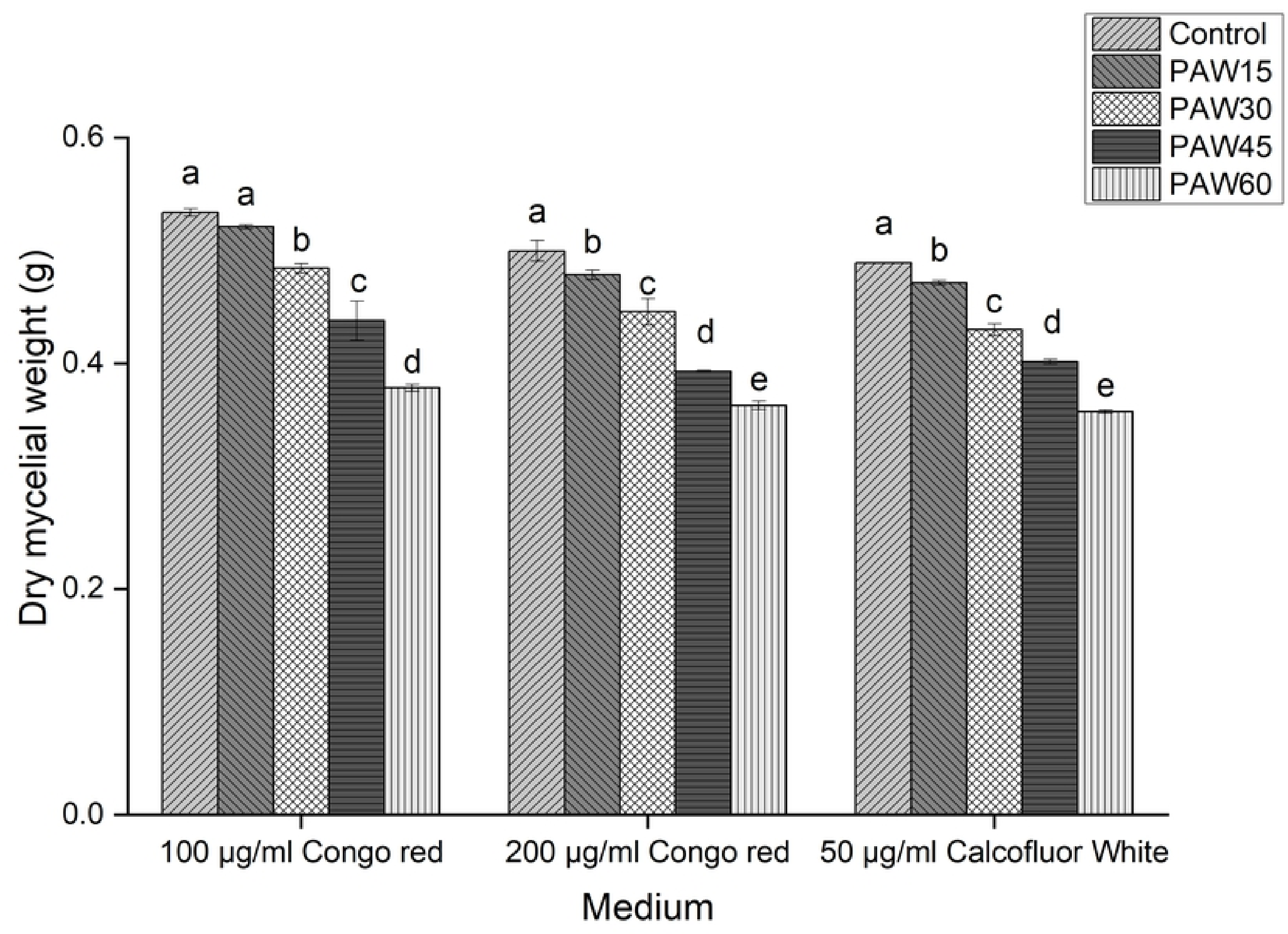

Figure3b 
a a a

a

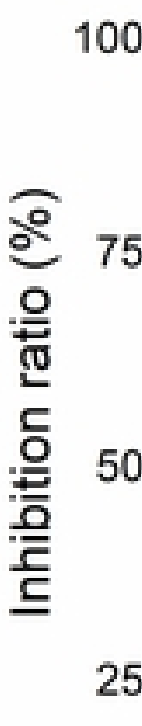

$100-$
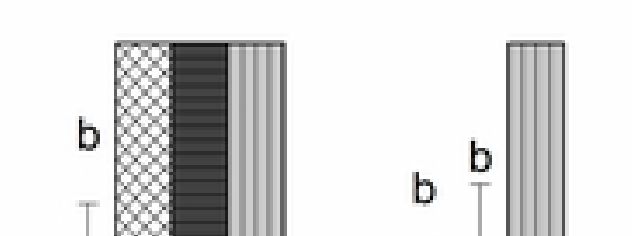

a



ab $T \quad$ a a

8 b因则 a

a
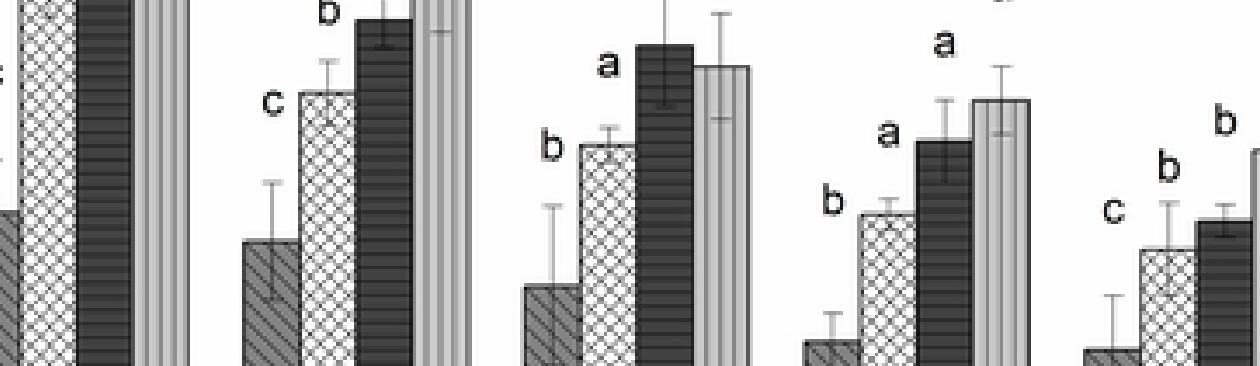

12

24

48

Figure3c 


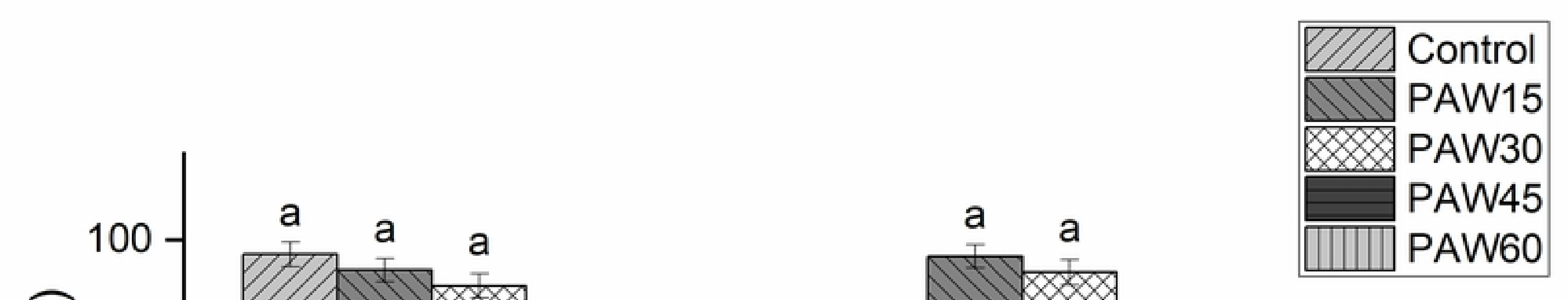

Figure3d

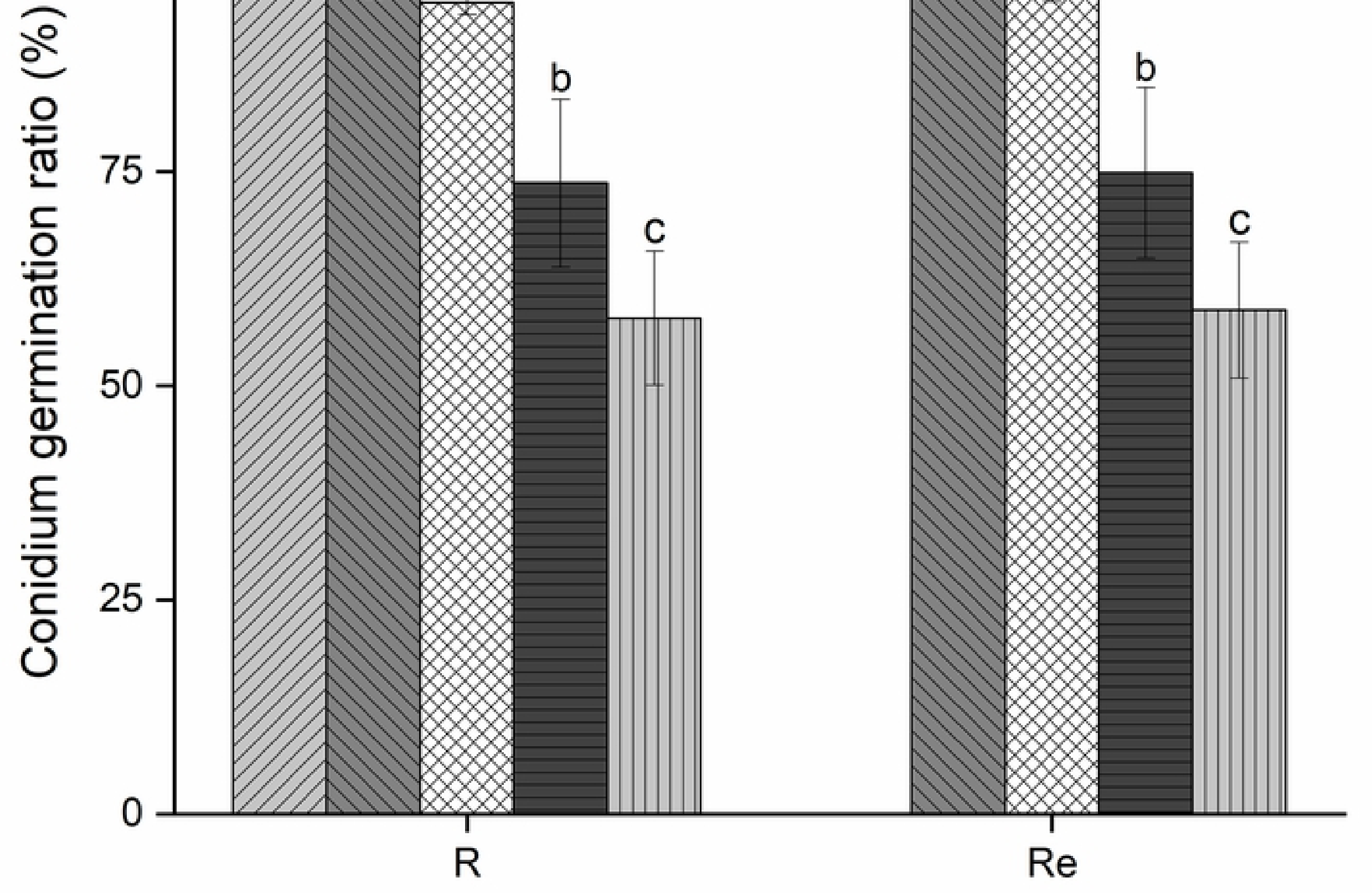




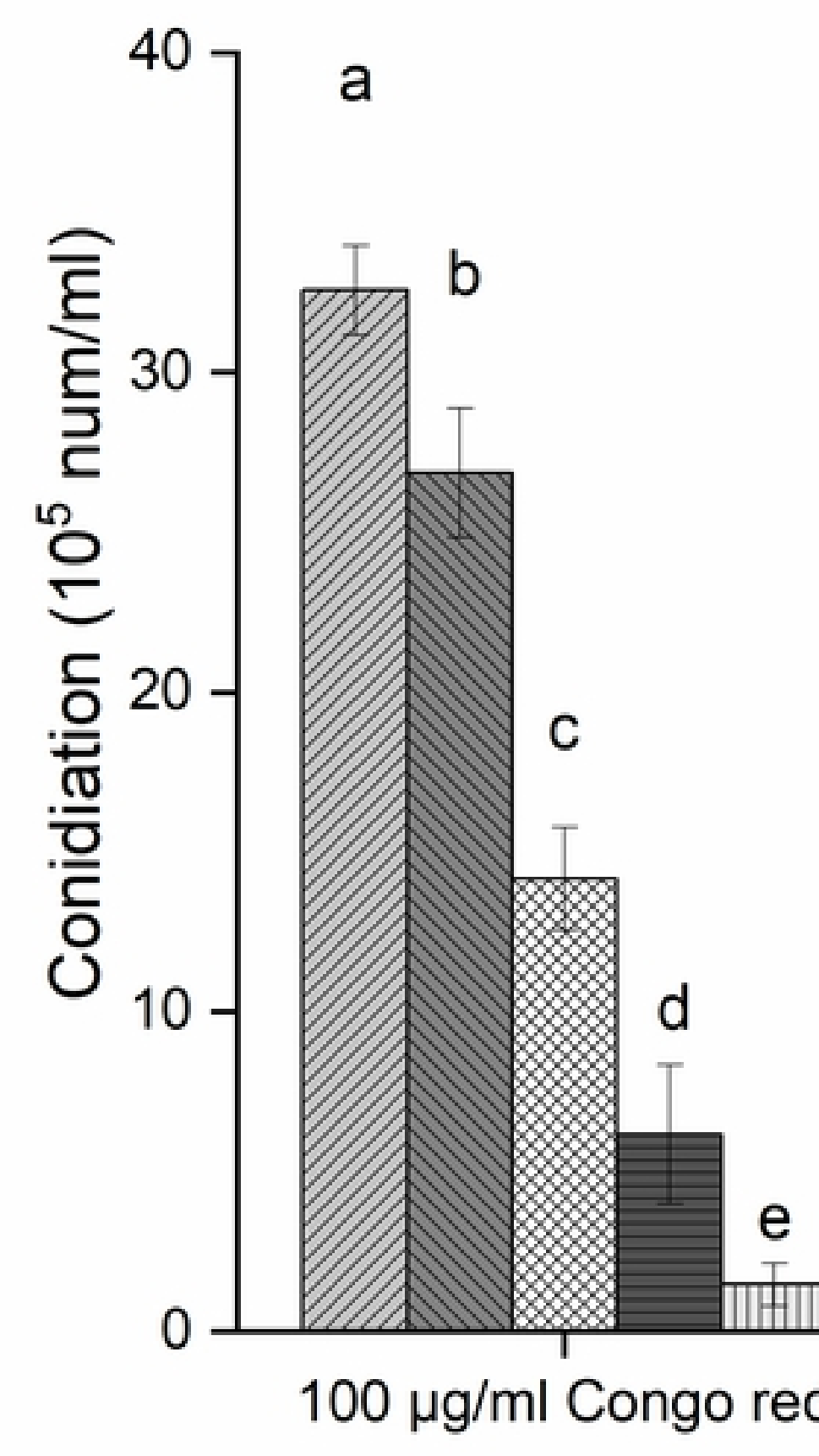

a

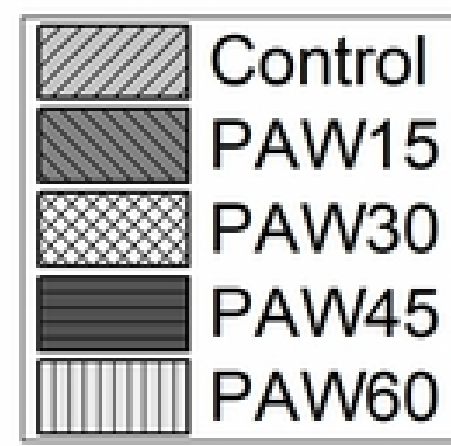

a

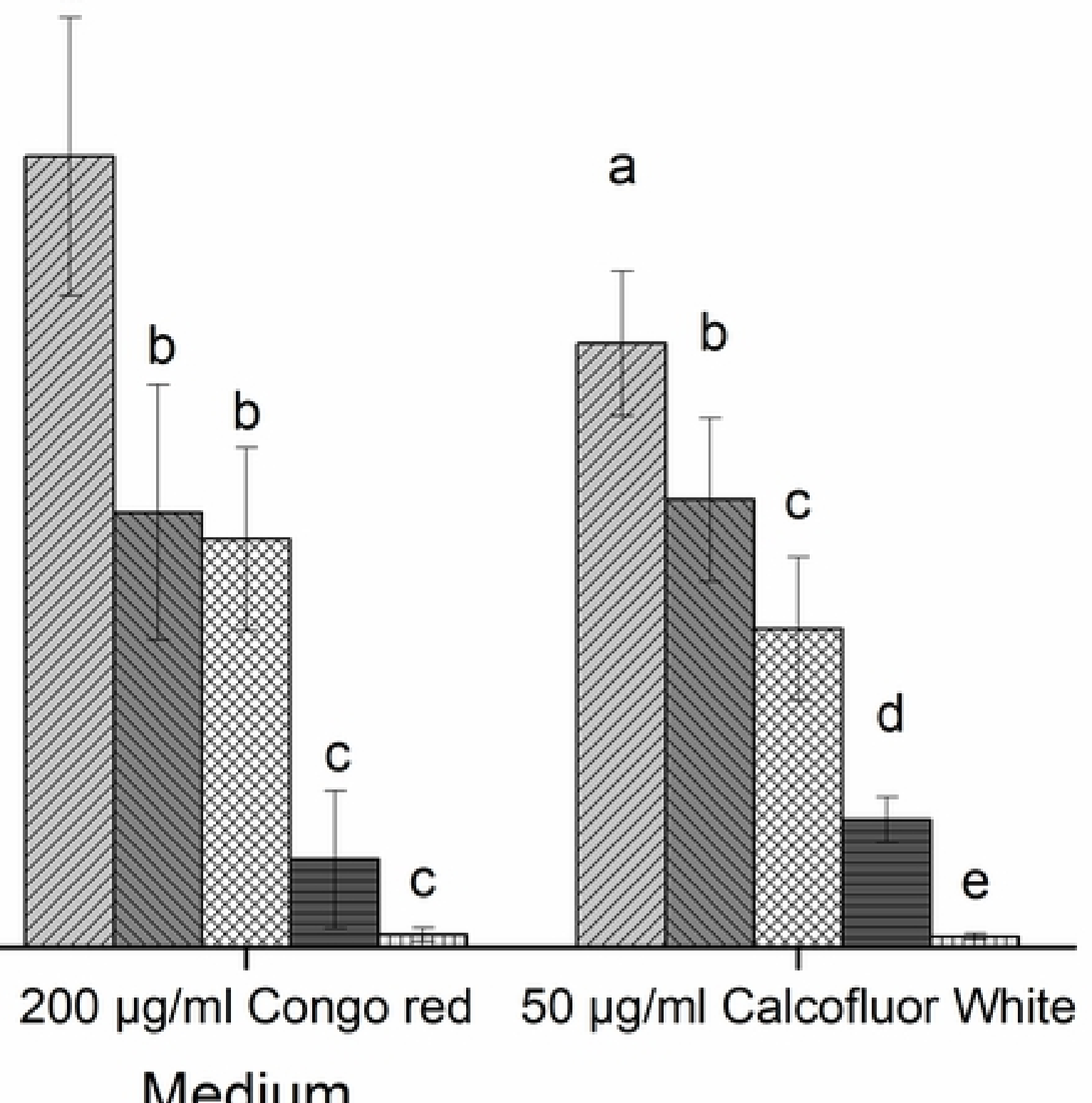

Medium

Figure3e



.


PAW60

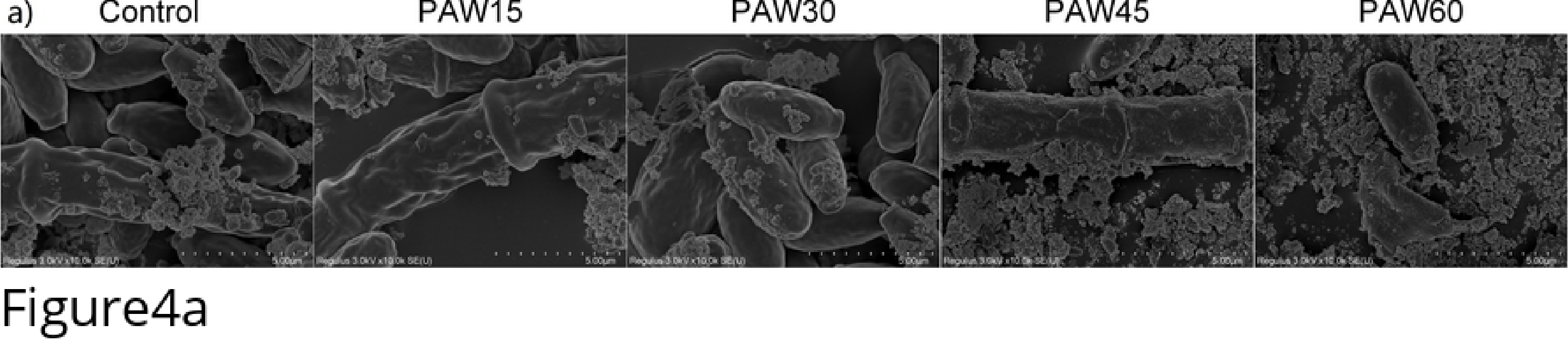

a) Control
Figure4a

PAW45
PAW30
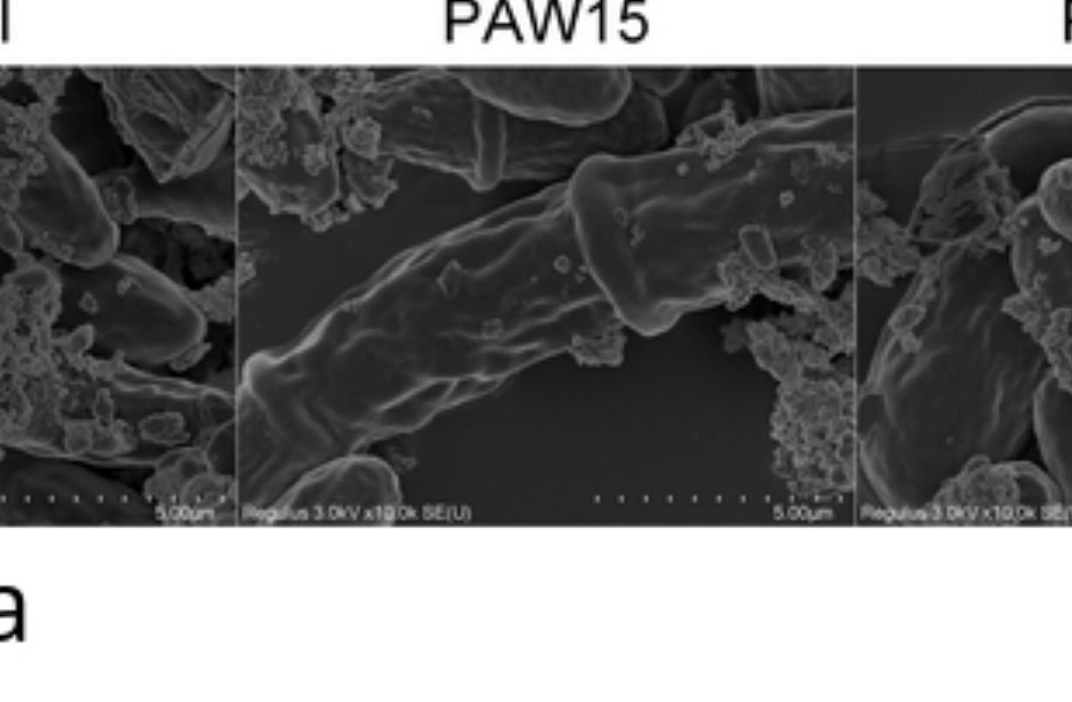
c) Control
Figure4c
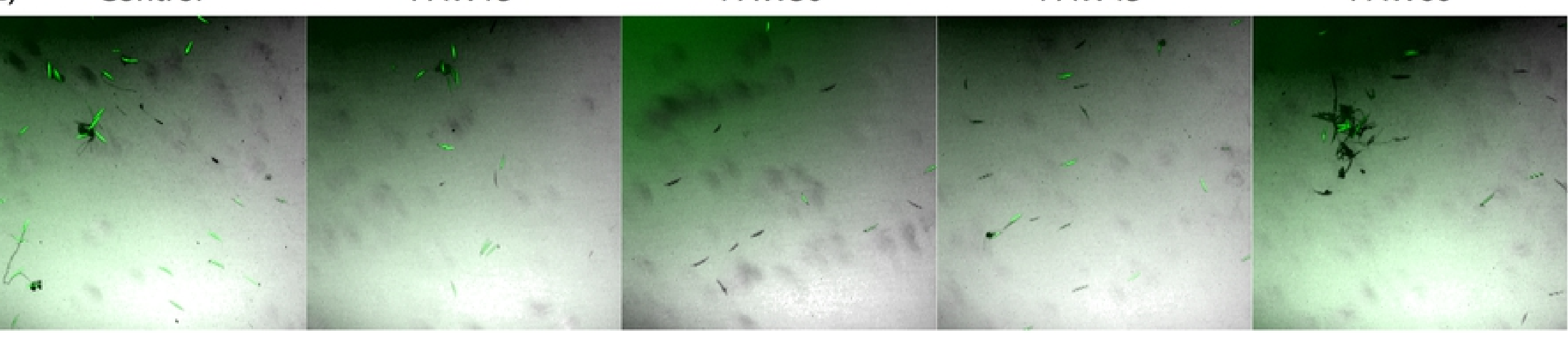

PAW15

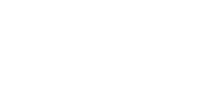 \\ PAW60}



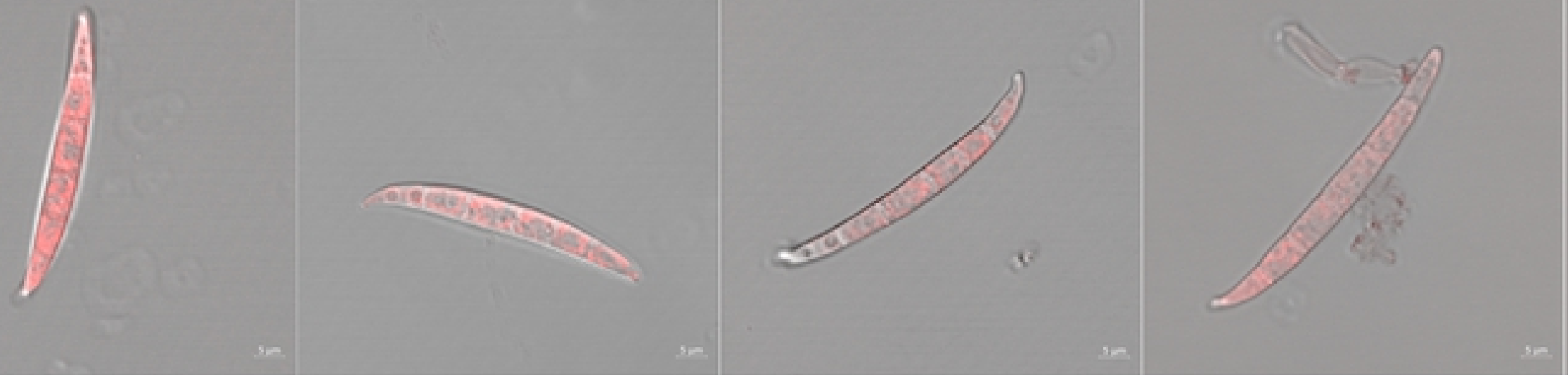

Figure5 


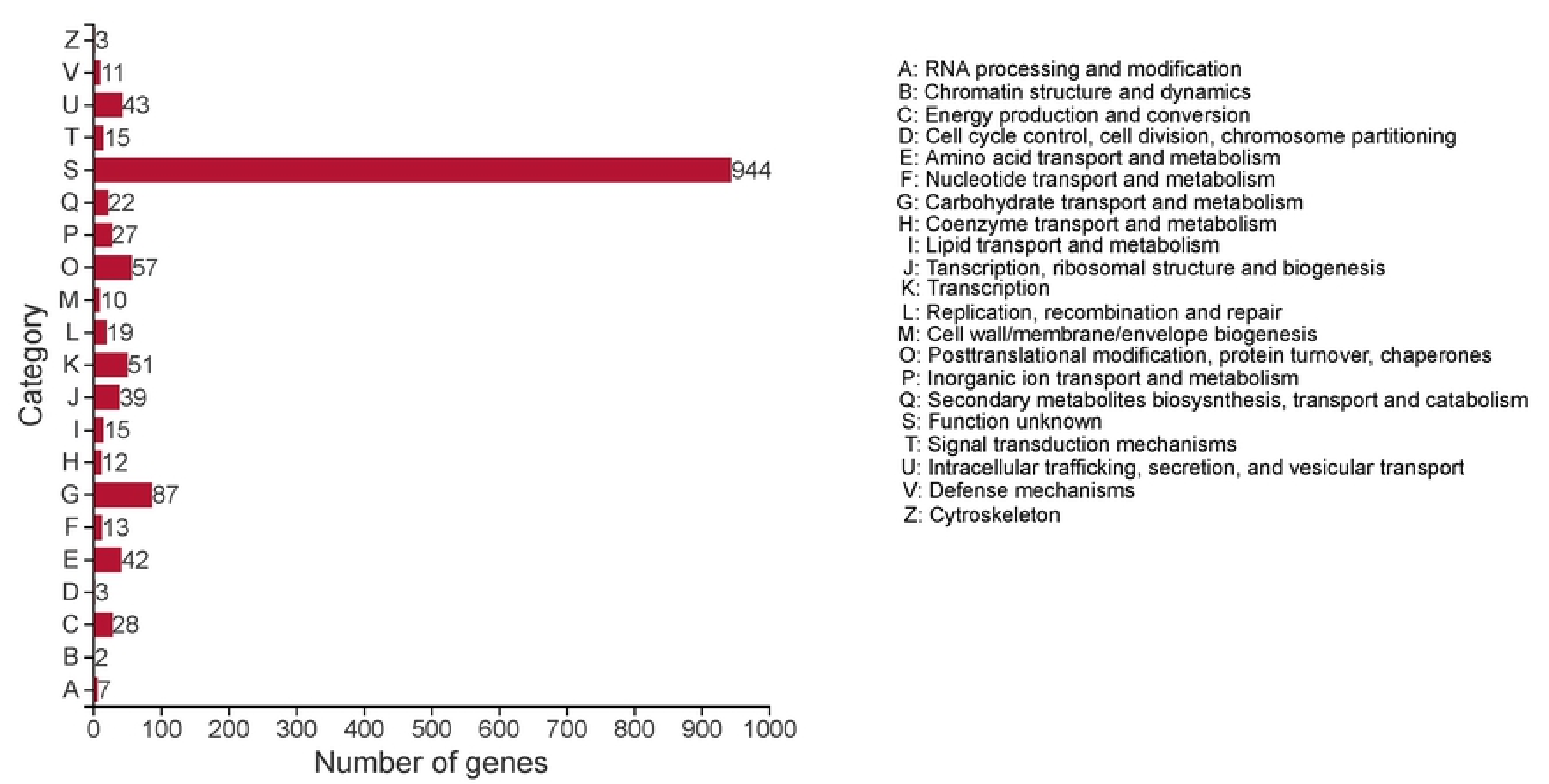

Figure6 